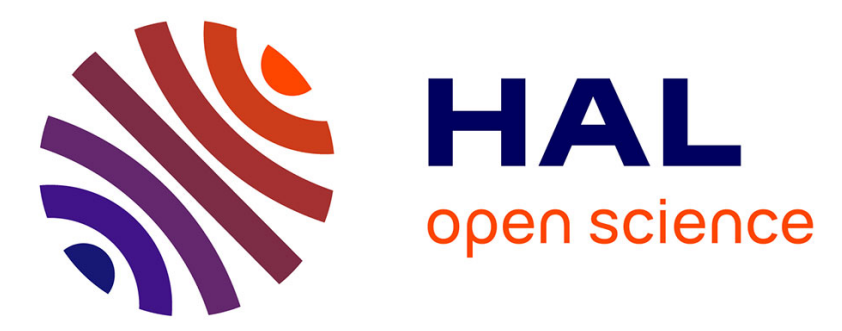

\title{
Speleoseismological Constraints on Ground Shaking Threshold and Seismogenic Sources in the Pollino Range (Calabria, Southern Italy)
}

Luigi Ferranti, Bruno Pace, Alessandro Valentini, Paolo Montagna, Edwige Pons-Branchu, Nadine Tisnérat-laborde, Laura Maschio

\section{To cite this version:}

Luigi Ferranti, Bruno Pace, Alessandro Valentini, Paolo Montagna, Edwige Pons-Branchu, et al.. Speleoseismological Constraints on Ground Shaking Threshold and Seismogenic Sources in the Pollino Range (Calabria, Southern Italy). Journal of Geophysical Research: Solid Earth, 2019, 124 (5), pp.5192-5216. 10.1029/2018JB017000 . hal-02457854

\section{HAL Id: hal-02457854 \\ https://hal.science/hal-02457854}

Submitted on 6 May 2021

HAL is a multi-disciplinary open access archive for the deposit and dissemination of scientific research documents, whether they are published or not. The documents may come from teaching and research institutions in France or abroad, or from public or private research centers.
L'archive ouverte pluridisciplinaire HAL, est destinée au dépôt et à la diffusion de documents scientifiques de niveau recherche, publiés ou non, émanant des établissements d'enseignement et de recherche français ou étrangers, des laboratoires publics ou privés. 
JGR Solid Earth

\section{RESEARCH ARTICLE 10.1029/2018JB017000 \\ Key Points: \\ - Six speleoseismic events in the Pollino area (southern Italy) during the last $\sim 42 \mathrm{ka}$, with 5.6-ka mean recurrence and 5.5-ka elapsed time \\ - Modeling of stalactite vulnerability is consistent with a fault-based seismic hazard model involving normal and strike-slip faults \\ - An 1-g PGA threshold for collapsed speleothems achieved every $5.6 \mathrm{ka}$ during strong $(\mathrm{M}>6)$ and close $(<12 \mathrm{~km})$ earthquakes; next one, pending}

Supporting Information:

- Supporting Information S1

- Table S1

- Table S2

- Table S3

- Table S4

Correspondence to:

L. Ferranti,

lferrant@unina.it

Citation:

Ferranti, L., Pace, B., Valentini, A.,

Montagna, P., Pons-Branchu, E., Tisnérat-Laborde, N., \& Maschio, L. (2019). Speleoseismological constraints on ground shaking threshold and seismogenic sources in the Pollino Range (Calabria, southern Italy). Journal of Geophysical Research: Solid Earth, 124, 5192-5216. https://doi.org/ 10.1029/2018JB017000

Received 7 NOV 2018

Accepted 26 APR 2019

Accepted article online 30 APR 2019

Published online 27 MAY 2019

(C)2019. American Geophysical Union. All Rights Reserved.
Speleoseismological Constraints on Ground Shaking Threshold and Seismogenic Sources in the Pollino Range (Calabria, Southern Italy)

\author{
Luigi Ferranti ${ }^{1}$ (D), Bruno Pace ${ }^{2}$ (D), Alessandro Valentini' ${ }^{2}$, Paolo Montagna ${ }^{3}$, \\ Edwige Pons-Branchu ${ }^{4}$ (D), Nadine Tisnérat-Laborde ${ }^{4}$ (D), and Laura Maschio ${ }^{5}$ \\ ${ }^{1}$ CRUST-DiSTAR, Università degli studi Federico II, Napoli, Italy, ${ }^{2}$ CRUST-DISPUTER, Università degli studi Gabriele \\ d'Annunzio, Chieti, Italy, ${ }^{3}$ Institute of Marine Sciences, ISMAR-CNR, Bologna, Italy, ${ }^{4}$ Laboratoire des Sciences du Climat \\ et de l'Environnement, LSCE/IPSL, CEA-CNRS-UVSQ, Université Paris-Saclay, Gif-sur-Yvette, France, ${ }^{5}$ THOLOS \\ GROUP s.r.l., Reggio Calabria, Italy
}

\begin{abstract}
Speleoseismological research carried out in the Pollino Range (Calabria, southern Italy), an area of alleged seismic gap in the active extensional belt running along the Southern Apennines, has placed constraints on the recurrence of $\mathrm{M}>6$ earthquakes, on the expected ground shaking threshold and on definition of seismogenic sources in the region. Radiometric (U-Th, AMS- ${ }^{14} \mathrm{C}$, and bulk- ${ }^{14} \mathrm{C}$ ) dating of before and after deformation layers from collapsed or tilted cave speleothems indicates that six speleoseismic events have occurred in the area during the last $\sim 42 \mathrm{ka}$, with a mean recurrence of $\sim 5.6 \mathrm{ka}$. Based on the in situ measured geometry and laboratory determined mechanical properties of speleothems and using an ad hoc seismogenic source model for northern Calabria, which involved both normal and strike-slip faults, we evaluate the seismic hazard at the cave sites. The numerical models to compute the ground horizontal acceleration threshold for speleothem failure was tested against intact and currently growing stalactites. The inferred age of these stalactites calibrated using established average speleothem growth rates of $0.3-1.2 \mathrm{~cm} / \mathrm{ka}$, ranges from $\sim 0.7$ to $\sim 10 \mathrm{ka}$, with most of them younger than $\sim 5.6 \mathrm{ka}$. Results show that the $\sim 0.8$ - to $1.0 \mathrm{-g}$ peak ground acceleration threshold estimated for collapsed speleothems every $5.6 \mathrm{ka}$ was achieved during strong $(\mathrm{M}>6)$ and close (epicentral distance $<12 \mathrm{~km}$ ) earthquakes. Considering a mean speleoseismic event recurrence of $5.6 \mathrm{ka}$ and that no speleoseismic shaking has occurred in the last $5.5 \mathrm{ka}$, the probability of occurrence of an $\mathrm{M}>6$ event in the area in the next few centuries is quite high.
\end{abstract}

Plain Language Summary Seismic shaking can cause collapse or tilt of cave speleothems (stalactites and stalagmites) and dating the calcite layers immediately after and before the deformation provides the age of unknown prehistorical earthquakes. By dating collapsed and tilted speleothems from the Pollino Range (Calabria, southern Italy), we built a catalog of six speleoseismic events that occurred in the last $\sim 42 \mathrm{ka}$ in the area. We defined a seismic hazard model for the cave sites using known or newly proposed seismic sources. The model was tested against an estimate of the vulnerability to seismic shaking for several unbroken and currently forming stalactites based on their geometry (slender speleothems are more vulnerable) and their mechanical properties measured in laboratory. Results indicate that a peak ground acceleration threshold of $\sim 1 \mathrm{~g}$ for speleothem collapse because of strong $(M>6)$ and close (distance $<12 \mathrm{~km}$ from the main seismogenic sources) is reached every $5.6 \mathrm{ka}$ and is in agreement with the age of unbroken speleothems ( $<10 \mathrm{ka}$, mostly $<5.6 \mathrm{ka}$ ). Considering a mean speleoseismic event recurrence of $5.6 \mathrm{ka}$ and that no speleoseismic shaking has occurred in the last $5.5 \mathrm{ka}$, an $\mathrm{M}>6$ event in the area is pending in the next few centuries.

\section{Introduction}

The analysis of speleothem deformation, such as breakage and collapse and offset of growth axis, is part of speleoseismological studies, which seek evidence of past earthquake within the cave archives (Becker et al., 2006, 2012; Forti, 2001). Radiometric dating of the deformation ("speleoseismic") events can be compared to historical seismicity catalogues (e.g.,Forti \& Postpischl, 1984; Postpischl et al., 1991) or be used to extend back in time the paleoseismological record (e.g., Becker et al., 2006; Delaby, 2001; Gilli \& Delange, 2001; Kagan et al., 2005; Lemeille et al., 1999; Perez-Lopez et al., 2009). 


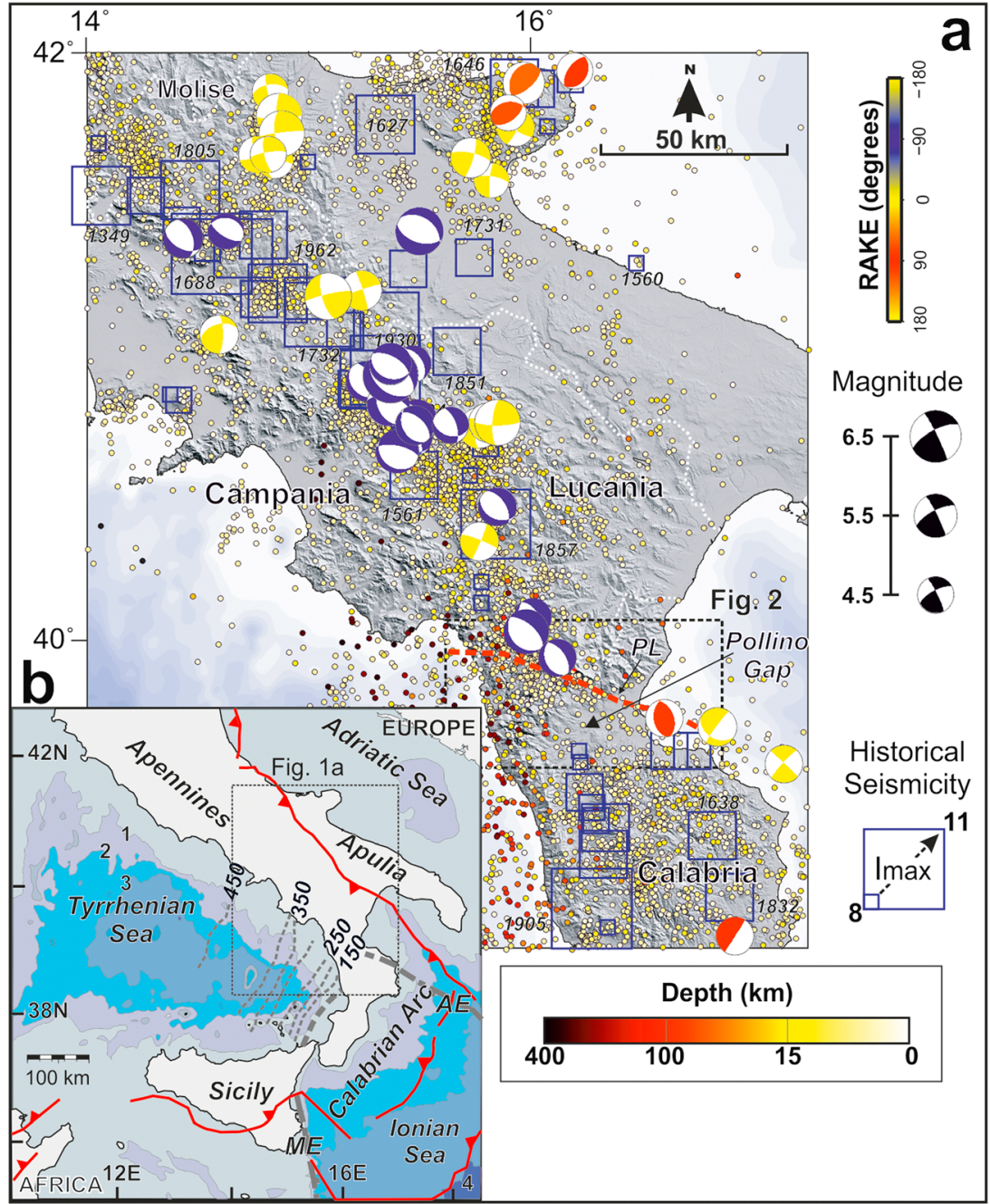

Figure 1. Seismotectonic setting of the Southern Apennines. Focal mechanisms compiled from literature and online catalogues for 1976-2012 earthquakes with $M \geq 4$.5. Focal mechanisms are colored according to rake: red $=$ thrust faulting; blue $=$ normal faulting; yellow $=$ strike-slip faulting. Blue squares are historical earthquakes from Catalogo Parametrico dei Terremoti Italiani (CPTI) catalogue (Rovida et al., 2016), with dates of most relevant events indicated; Imax $=$ maximum macroseismic intensity. Dots colored according to depth are instrumental seismicity $(\mathrm{M} \geq 2.2)$ during 1983-2012 (http://iside.rm.ingv.it). Red dashed line is the Pollino Line (from Van Dijk et al., 2000). (b) Geodynamic setting of the central Mediterranean (modified from Ferranti, Burrato, et al., 2014); red lines are the regional contractional structures; dotted dark gray lines are isobaths of the Ionian slab, thicker dark gray dashed lines are the conjugate continental margins of the Ionian Sea ( $\mathrm{AE}=$ Apulian Escarpment; $\mathrm{ME}=$ Malta Escarpment).

The underlying idea is based on the stalactite-stalagmite oscillatory system, which represents the vertical datum. If other sources (landslide, flooding, ice flow, and animal or anthropic passage) of deformation can be excluded, the deviation of the growth axis from the vertical, and the speleothem breakage, are evidence for tilting and faulting of the block hosting the cave and for shaking of the cavity walls, respectively (Forti \& Postpischl, 1984; Kagan et al., 2005). However, the difficulty in quantitative modeling of the observed deformation and its direct attribution to a seismogenic source remains a major issue (Becker et al., 2006; Lacave et al., 2004; Pons-Branchu et al., 2004).

The Pollino Range is located in the northern Calabria sector of the Apennines, which currently experiences extension, as documented by seismicity, geodesy, and active fault studies (Figure 1a; Papanikolau \& Roberts, 2007; Ferranti, Palano, et al., 2014). The axial belt of the Apennines is a region of high seismic hazard testified by historical and instrumental seismicity catalogues with several large $(6.5 \leq \mathrm{M} \leq 7.5)$ and destructive events (Figure 1a; Galli et al., 2008; Rovida et al., 2016). Although the largest earthquakes have been 




Figure 2. Active tectonics of Northern Calabria. Boxes are epicenters of $\mathrm{M}>4.5$ historical (blue) and instrumental (red) earthquakes scaled according to M derived from the CPTI15 database (Rovida et al., 2016). Active faults (red solid or dashed lines) compiled from various sources (as summarized in Brozzetti et al., 2017; Ferranti, Palano, et al., 2014; Ferranti, Burrato, et al., 2014): $\mathrm{MF}=$ Mercure Fault; $\mathrm{CF}=$ Castrovillari Fault; WPF = Western Pollino Fault; EPF = Eastern Pollino Fault; STSF $=$ Satanasso Fault; AMF = Amendolara Fault; RF = Rossano Fault; $\mathrm{SF}=$ Sybaris Fault. Dashed boxes are the modeled seismogenic sources: MS $=$ Mercure Source; CS = Castrovillari Source; EPS = Eastern Pollino Source; STSS $=$ Satanasso Source; AMS = Amendolara Source; RS = Rossano Source; the solid line associated to each box is the surface projection of the source plane. Blue polygons are the caves studied in this paper: $\mathrm{SG}=$ Serra del Gufo; DA = Damale; SA = S. Angelo; RH = Rüah; $\mathrm{MO}=$ Morano. Yellow polygon is Romito cave, studied by Kagan et al. (2017). associated to a causative fault (DISS, WG 2018, and references therein), uncertainties still surround the definition of source geometric, kinematic, and energetic parameters in some areas along the belt. This uncertainty represents a severe drawback for the growing practice of seismic hazard estimation based on tectonic information for individual seismogenic sources (e.g., Pace et al., 2006; Peruzza et al., 2010; Valentini et al., 2017).

Northern Calabria, and specifically the Pollino Range, represents a sector of poorly defined hazard because of the lack of significant earthquakes (Figure 1a) within the $\sim 500$ years completeness interval for $\mathrm{M}>6$ events (Rovida et al., 2016). Based on paleoseismological trench data, the PollinoCastrovillari seismogenic source, which underlies to the south the Pollino Range (Figure 2), can potentially generate $\mathrm{M} \sim 7$ earthquakes every 1-3 ka (Cinti et al., 1997, 2002; Cinti, Pauselli, et al., 2015; Michetti et al., 1997). However, the lack of significant $(M>5.9)$ events in historical and instrumental catalogues (Rovida et al., 2016) has led previous workers to suggest that the Pollino area spatially coincides with a seismic gap, and the hazard level is considerably higher than surrounding regions.

Research on broken or damaged speleothems from caves in northern Calabria has provided additional information on large earthquakes that shocked the region during the last $\sim 40$ ka (Ferranti et al., 1997; Ferranti \& Maschio, 2007; Kagan et al., 2017). Although paleoseismological constraints derived from investigation of broken speleothems are pivotal for the enlargement of seismic catalogues backward in time, they do not offer information on the causative seismogenic sources and on the threshold magnitude experienced in the Pollino region.

In this paper, we use a more complete approach by integrating the refined speleoseismic catalog with an analysis of the speleothem vulnerability to seismic shaking and an ad hoc fault-based seismic hazard model.

Results of this work offer a new perspective in the estimation of the seismic hazard of the Pollino region and highlight the performance of integrated speleosesimological and seismic hazard studies.

\section{Background Setting}

\subsection{Regional Frame}

The Pollino Range marks the boundary between the Southern Apennines fold-and-thrust belt in the north and the Calabrian Arc accretionary wedge in the south (Figure 1b). The Southern Apennines and Calabrian Arc formed in response to west and northwest-directed subduction and delamination of the Adriatic (or Adria) block (Figure 1b). The Adria block represents a lithospheric fragment trapped within the Africa and Europe collision boundary and composed of continental crust in the Adriatic-Apulian domain and oceanic crust in the Ionian domain (Faccenna et al., 2001).

In the hinterland of the Apennines, Late Pliocene-Quaternary extension related to stretching of the Tyrrhenian back-arc basin followed contraction (Figure 1b; Patacca et al., 1990), and transtensional and extensional faults crosscut the thrust structures forming coastal and intermountain basins (Hyppolite et al., 1994). Extension progressed from west to east, and since the Middle Pleistocene, an array of normal faults formed along the $\sim 30$-km-wide axial part of the chain, where it includes major recognized seismogenic structures (Figure 2).

Within the active extensional belt, moderate to large (Mmax 7) earthquakes occur at focal depths of $\sim 10-13$ $\mathrm{km}$ and exhibit focal mechanisms with primarily normal faulting features and tensile axis roughly orthogonal to the chain (Figure 1a). Seismological observations are consistent with fault-slip data from Quaternary rocks (Faure Walker et al., 2012; Maschio et al., 2005; Papanikolau \& Roberts, 2007), and with GPS geodetic velocities (Ferranti, Palano, et al., 2014). In the eastern sector of southern Italy, including the now inactive frontal sector of the chain and the foreland, strike-slip faulting characterizes the active deformation pattern. 


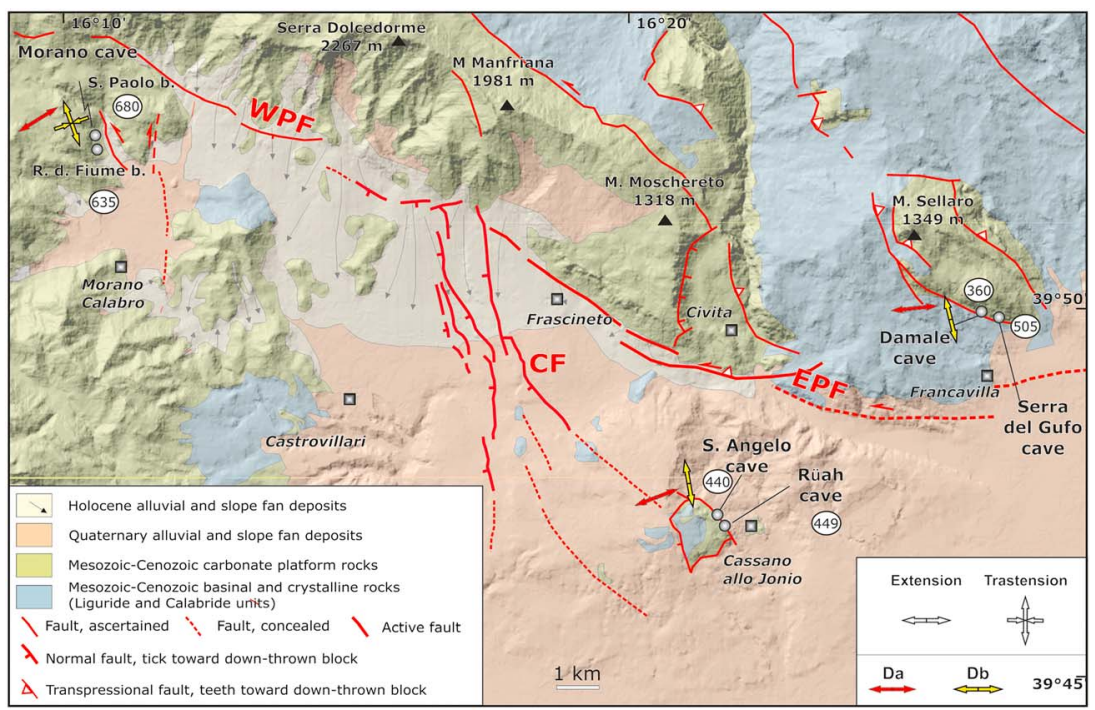

Figure 3. Geological map of the southeast Pollino Range, with location of the studied caves. Arrows indicate the trend of the finite extension axes as determined by inversion of faults slip data, grouped according to slip events $\mathrm{Da}$ and $\mathrm{Db}$ (see Figure 5). The circled numbers are the elevation (in meters above sea level) of the cave entrances. Generalized geology and fault traces adapted after Geological Map of Italy, 1:100.000 scale, sheet n. 221, Castrovillari. Active fault traces after Ferranti et al. (2009), DISS, WG (2018) and Brozzetti et al. (2017). Faults labels as in Figure 2.

Focal depths ( $\sim 15-35 \mathrm{~km})$ of seismic sequences in the eastern region are deeper than focal depths of the extensional earthquakes in the west (Boncio et al., 2007).

A limit of regional significance separates the Southern Apennines in the north and the Calabrian Arc in the south. This boundary has a $\sim$ WNW-ESE trend and stretches from the Tyrrhenian to the Ionian margin of southern Italy (Figure 1a). The surface expression of this limit broadly coincides with the Pollino Line (PL, Figure 1a), a transcurrent shear zone with associated tensional and compressional features (Ghisetti \& Vezzani, 1982; Van Dijk et al., 2000). In the east, the boundary continues offshore the Ionian Sea (Figure 1a), where marine geophysical studies suggest recent left transpressional activity (Ferranti, Burrato, et al., 2014).

The surface and upper crustal limit spatially overlaps a deep (down to 60-80 km) boundary that separates lower crustal and lithospheric domains characterized by low- and high- $V p$ values in the Southern Apennines and in the Calabrian Arc, respectively (Chiarabba et al., 2016; Totaro et al., 2013). The deep discontinuity forms the northern lateral edge of the Ionian slab subducted underneath the Tyrrhenian Sea and developed at the expenses of the northern continental margin of the Ionian Mesozoic ocean basin (Figure 1b; Faccenna et al., 2011).

The active role of this boundary is documented by sharp changes in the seismicity epicentral distribution, in the style of seismic faulting (Presti et al., 2013; Totaro et al., 2013), and in geodetic velocity fields (Ferranti, Palano, et al., 2014). Ferranti, Palano, et al. (2014) showed that the belt of geodetic extension in the Apennines interrupts in northern Calabria and resumes further south in Calabria, and the Pollino region marks this sharp transition. According to Chiarabba et al. (2016), the lithospheric-scale discontinuity causes a segmentation of the belt of normal faults across the range, limiting the lateral extent of faults where future earthquakes might occur.

\subsection{Active Deformation in the Pollino Region}

The Pollino Range is underlain by Mesozoic-Cenozoic platform carbonates and minor Miocene silicilastic rocks (Figure 3), which were displaced toward the northeast during Miocene-Pliocene contractional tectonism. Sinistral shear along the Pollino Fault (the central part of the wider PL that cuts across northern Calabria, Figure 1a), which marks the base of the $~ 1.5-\mathrm{km}$-high southern flank of the mountain range, dominated Quaternary deformation (Figure 2; Ghisetti \& Vezzani, 1982; Van Dijk et al., 2000). Slip on the Pollino 
Fault controlled the growth of small intermountain basins at fault bends that were filled by alluvial, slope, and lacustrine deposits (Russo \& Schiattarella, 1992; Spina et al., 2009).

Despite the fact that the Pollino Fault is typically regarded as a single structure (e.g., Papanikolau \& Roberts, 2007), we consider it as composed by two distinct segments that differ in trend and kinematic evolution (Figures 2 and 3). The $18-\mathrm{km}$-long Western Pollino Fault (WPF), although is characterized by dominant Early Pleistocene left transtension, bears evidence of a later extensional reactivation (Schiattarella, 1998). The current activity of the WPF is debated. Based on paleoseismological trench data (Michetti et al., 1997) and morphostructural analysis, it was proposed that the WPF is an active fault and has a slip rate of 0.3 $\mathrm{mm}$ /year (Papanikolau \& Roberts, 2007). Brozzetti et al. (2017) instead documented that the fault is cut by NNW-SSE striking faults and claimed that it is no longer active.

The $\sim 12-\mathrm{km}$-long eastern segment of the Pollino Fault (EPF) is characterized by transpression throughout the Pleistocene (Catalano et al., 1993; Ferranti et al., 2009; Spina et al., 2009). Active left transpression on the EPF at $0.4 \mathrm{~mm} /$ year is suggested by structural analysis of recent deposits and by geomorphic anomalies (Ferranti et al., 2009).

The NNW-SSE striking Castrovillari Fault (CF) is a normal fault array composed of three anastomosing west-dipping subparallel segments that link at shallow depth and merges with the WPF immediately to the northwest of Frascineto village (Figure 3; Cinti et al., 2002; Cinti, Pauselli, et al., 2015). Paleoseismological trenching revealed two events with inferred M 6.5-7 in the last 1.5 ka on both the easternmost part of WPF and on the CF and two previous events of comparable size between 30 and $2.4 \mathrm{ka}$ on the CF (Michetti et al., 1997; Cinti et al., 1997, 2002; Cinti, Pauselli, et al., 2015). Trenching results suggest a Holocene slip rate of 0.2-0.6 mm/year and a recurrence of 1-3 ka for large earthquakes (Cinti et al., 2002; Cinti, Pauselli, et al., 2015). The long-term (Middle Pleistocene) vertical slip rate of the CF is $\sim 0.25$ $\mathrm{mm}$ /year (Cinti, Pauselli, et al., 2015; Spina et al., 2009). The geomorphologic evidence of recent deformation on the CF can be clearly mapped for a total length of 10-13 km (Cinti et al., 1997, 2002), but evidence is lost in the Sibari Plain to the south. Based on the 1-m slip per event inferred from paleoseismological trenches and on regression of source parameters from empirical relations (Wells \& Coppersmith, 1994), Cinti et al. (2002) suggested that the fault might extend further south in the Sibari Plain where it is concealed by recent alluvium, for a total length of $\sim 20 \mathrm{~km}$.

East of the EPF, the transpressional belt steps to the north of the Sibari Plain, where the deformation pattern of Middle Pleistocene-Holocene marine terraces suggests activity of an 18-km-long, blind left-reverse fault, with a slip rate of $0.4 \mathrm{~mm} /$ year (STSF, Figure 2; Santoro et al., 2009, 2013). Evidence of active deformation is also recorded in the central part of the Sibari Plain. Here archeoseismic research in the ancient Sybaris site has documented a tectonic signal superposed to compaction subsidence (Cucci, 2005; Ferranti et al., 2011), and fractures and faults affecting Hellenistic-age masonry (Cinti, Alfonsi, et al., 2015). Cinti, Alfonsi, et al. (2015) proposed that the observed coseismic damages are related to slip along the NE-SW trending dextral transtensional Sybaris Fault zone (Figure 2) during a Late Classical to Medieval earthquake, which was nucleated either on the latter fault $(M \sim 5.5-6)$ or on an off-site structure $(M \geq 6)$ that they suggest to be the CF. Dextral motion on the NE-SW striking Sybaris Fault is kinematically consistent with left motion on the WNW-ESE striking faults (Figure 2) in the context of ENE-WSW contraction acting in the Ionian side of northern Calabria (Ferranti et al., 2009; Ferranti, Palano, et al., 2014).

Offshore the Sibari plain, Pleistocene left transpression is documented by marine geophysical data (Ferranti, Burrato, et al., 2014) along the southern flank of the Amendolara Ridge, the submarine continuation of the PL (Figure 2). Ferranti, Burrato, et al. (2014) proposed that the 18-km-long Amendolara Fault (Figure 2) is an active blind transpressional fault with a slip rate of $0.5 \mathrm{~mm} /$ year.

Active strike-slip motion is also inferred along the $~ 30-\mathrm{km}$-long Rossano Fault (RF) south of the Sibari Plain, with a horizontal slip rate of 1-2 mm/year (Figure 2; Ferranti, Palano, et al., 2014; Galadini et al., 2000; Tansi et al., 2007; Van Dijk et al., 2000). Although some researchers suggested the fault is extensional (Galli et al., 2010), current strike-slip motion is suggested by seismicity analysis (Presti et al., 2013).

West of the WPF, active extension on the Mercure Fault (MF), which bounds to the north a basin filled by Quaternary deposits, is suggested by morphotectonic and seismicity data (Brozzetti et al., 2017). Analysis of recent low magnitude seismicity underneath the Mercure Basin revealed that, underneath a 10- to 12-km- 
thick upper crust affected by extensional seismicity, strike-slip earthquakes continue down to $\sim 20-\mathrm{km}$ depth and align along the broadly defined boundary between Southern Apennines and Calabrian Arc (Ferranti et al., 2017).

Only moderate ( $\mathrm{M}<6$; I $\leq$ VIII-IX MCS) earthquakes have struck the Pollino region and surroundings in historical time (Figure 2; Rovida et al., 2016; Tertulliani \& Cucci, 2014). The maximum intensities are related to the 1708 (I $\leq$ VIII-IX) and the 1693 (I $\leq$ VII) events. Significant seismic events in the instrumental era are represented by the 1998, MW $=5.6$ ( $\leq$ VII) earthquake in the Mercure Basin west of the Pollino Range and by the 2010-2014 Mw $\leq 5.3$ Pollino seismic sequence (Figure 2). Because of the discrepancy between the seismicity record and the paleoseismological trench data, the Pollino area is regarded as the major seismic gap in the Apennines extensional belt (Cinti et al., 2002; Cinti, Pauselli, et al., 2015).

Speleoseismological investigations provided additional information on prehistorical shaking events in the Pollino area. Ferranti et al. (1997) and Ferranti and Maschio (2007) studied broken or damaged speleothems from five caves on the southern side of the range (Figure 3). Based on ${ }^{14} \mathrm{C}$ radiometric dating, Ferranti and Maschio (2007) identified seven speleoseismic events in the last $\sim 45 \mathrm{ka}$, with a recurrence of $\sim 6.5 \mathrm{ka}$. By integrating data from the Morano Cave and from the Romito Cave located west of the Pollino Range (Figure 2), Kagan et al. (2017) documented three speleoseismic events that occurred in the last $\sim 28 \mathrm{ka}$, with a maximum recurrence interval of $\sim 9 \mathrm{ka}$. Only the oldest of those ((27.4-28.4 ka) was recorded in the Morano Cave, which is included in our study. They also found two widely bracketed additional events at $\sim 79-20 \mathrm{ka}$ and $\sim 65-15 \mathrm{ka}$ at Morano. Because the $2012 \mathrm{Mw}=5.3$ earthquake, which occurred during the Pollino seismic sequence did not cause any observable effect in the visited caves, Kagan et al. (2017) considered this magnitude size as a lower threshold for producing permanent speleoseismic effects. They further suggested that the youngest $(7.4-2.9 \mathrm{ka})$ speleoseismic event could be related to the 2.4- to 4.0-ka rupture found in the $\mathrm{CF}$ trenches (Cinti et al., 2002).

\section{Methods}

\subsection{Speleothem Sampling and Structural Analysis}

For the present study, we investigated five caves: Morano (composed by San Paolo and Ramo del Fiume branches), Sant'Angelo, Rüah, Damale, and Serra del Gufo (Figure 3), already investigated by Ferranti et al. (1997) and Ferranti and Maschio (2007). We measured the geometry of intact speleothems (Figure 4a) using a tape and sampled by hammer a selection of both intact and collapsed speleothems for radiometric dating and geomechanical tests.

Four classes of deformation typologies that affect speleothem and other cave concretions were distinguished (cf. Becker et al., 2006). A first class includes the collapse of speleothems, which are often surmounted by younger and intact stalagmites (Figure $4 \mathrm{~b}$ ) and is indicative of seismic shaking. A second class contains both tensional and shear fractures and low-angle shear surfaces cutting obliquely through columns (Figures 4e, 4f, and 4g). These latter features are characterized by speleothem offset of some millimeters to centimeters locally accompanied by rotation around the vertical axis (Figure 4e), which suggests sliding and vertical contraction.

A change in trend of the growth axis of stalagmites, and occasionally stalactites, where the youngest layers (or laminae) maintain alignments with the vertical direction (Figure 4d), defines a third class. The deviation of the growth axis of a speleothem from the vertical can be associated to several sources including cave flooding by ice or water (e.g., Jaillet et al., 2006), but in regions of vigorous seismic activity like the Apennines, the most likely cause (Forti \& Postpischl, 1984) is coherent tilt of the concretion and of its bedrock (Becker et al., 2006). Such a tilt would imply either a low ground shaking, not able to cause speleothem collapse, or a substantial component of creep.

Finally, erosional truncations between laminae, revealed by sawing apparently intact concretions, represent additional evidence of deformation (see several examples in Text S1 in the supporting information S1). These truncations mark sudden changes in growth conditions that can be related to fracturing or faulting.

Based on cave topography and elevation above sea level (Figures 3 and S1-S5) and on the geomorphological setting, we exclude that the observed speleothem deformation is the result of processes acting at a local scale, such as landslides, flooding, flow of ice during past glacial stages, and animal or anthropic passage (Becker 

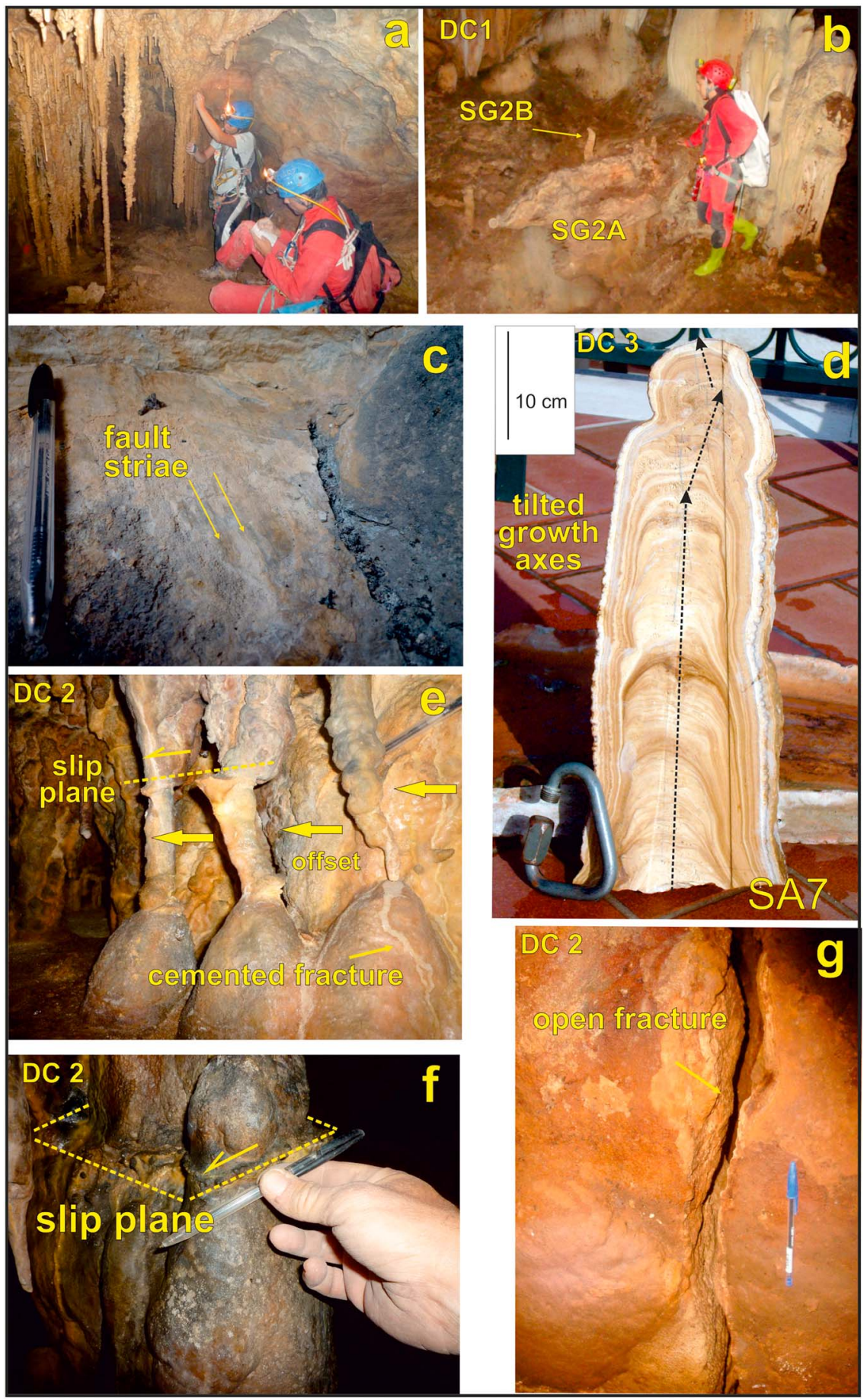

Figure 4. Speleothems from the Pollino caves: (a) measuring the geometry of active stalactites in the conduit beneath the P9 (Branch A, Serra del Gufo); (b) collapsed stalagmite SG2A, which was regrown by stalagmite SG2B (Branch C, Serra del Gufo); (c) striated fault plane in bedrock (Damale Cave); (d) stalagmite SA7 with tilted growth axes (S. Angelo Cave); (e) offset and fractured columns with cemented fractures (S. Angelo Cave); (f) low-angle shear planes within small columns (S. Angelo Cave); (g) high-angle open fracture within concretions (Morano Cave, S. Paolo branch). $\mathrm{DC}=$ deformation class number.

et al., 2012; Ferranti \& Maschio, 2007; Jaillet et al., 2006; Kagan et al., 2005, 2017). The possible occurrence of nonseismic amplification of the ground motion is an uncertainty that we did not treat in this work but that can be solved in future studies using microearthquakes or microtremors records outside and inside the caves. 
Table 1

Information on Structural Data Collected Inside and Outside the Studied Caves and Computed Extension Axes From Inversion of Fractures and Fault Slip Lineation

\begin{tabular}{|c|c|c|c|c|c|c|c|}
\hline Sector & Site & $\begin{array}{c}\text { Faulted/fractured } \\
\text { lithology }\end{array}$ & $\begin{array}{l}\text { Kinematic } \\
\text { Indicator }\end{array}$ & $\begin{array}{c}\text { Data } \\
\text { number }\end{array}$ & $\begin{array}{c}\text { Extension axis } \\
(\mathrm{T} / \mathrm{P})\end{array}$ & $\begin{array}{l}\text { Tectonic } \\
\text { regime }\end{array}$ & $\begin{array}{l}\text { Deformation } \\
\text { phase }\end{array}$ \\
\hline \multirow[t]{5}{*}{ Cassano block } & \multirow[t]{2}{*}{ Outside S. Angelo Cave } & \multirow[t]{2}{*}{ Tr-Early J carbonate } & FSL & 13 & $69 / 11$ & $\mathrm{~N}$ & $\mathrm{Da}$ \\
\hline & & & FSL & 6 & $170 / 7$ & $\mathrm{~N}$ & $\mathrm{Db}$ \\
\hline & \multirow{3}{*}{ S. Angelo Cave } & \multirow{3}{*}{ Q Speleothems } & FR & 5 & 90 & - & $\mathrm{Da}$ \\
\hline & & & & 2 & 178 & - & $\mathrm{Db}$ \\
\hline & & & TLT & 5 & 301 & - & $\mathrm{Db}$ \\
\hline \multirow[t]{7}{*}{ Sellaro block } & \multirow[t]{2}{*}{ Outside Damale Cave } & \multirow[t]{2}{*}{$\mathrm{K}$ limestone } & FSL & 6 & $84 / 13$ & $\mathrm{~N}$ & $\mathrm{Da}$ \\
\hline & & & FSL & 7 & $166 / 10$ & N_SS & $\mathrm{Db}$ \\
\hline & \multirow[t]{2}{*}{ Damale Cave } & $\mathrm{K}$ limestone & FSL & 1 & - & - & $\mathrm{Da}$ \\
\hline & & Q speleothems & FR & 2 & 334 & - & $\mathrm{Db}$ \\
\hline & \multirow[t]{3}{*}{ Serra del Gufo Cave } & \multirow[t]{2}{*}{ Q speleothems } & FR & 2 & 51 & - & $\mathrm{Da}$ \\
\hline & & & FR & 1 & 318 & - & $\mathrm{Db}$ \\
\hline & & Q speleothems & TLT & 5 & 62 & - & $\mathrm{Da}$ \\
\hline \multirow[t]{5}{*}{ Morano block } & \multirow[t]{2}{*}{ Outside S. Paolo-RdF cave } & \multirow{2}{*}{$\mathrm{J}$ carbonate } & FSL & 3 & $58 / 1$ & $\mathrm{~N}$ & $\mathrm{Da}$ \\
\hline & & & FSL & 3 & $160 / 10$ & SS_N & $\mathrm{Db}$ \\
\hline & \multirow[t]{3}{*}{ S. Paolo-Ramo del Fiume Cave } & \multirow{3}{*}{$\begin{array}{l}\text { J carbonate } \\
\text { Q speleothems }\end{array}$} & FSL & 2 & $204 / 7$ & SS & $\mathrm{Db}$ \\
\hline & & & FR & 3 & 40 & - & $\mathrm{Da}$ \\
\hline & & & FR & 9 & 305 & - & $\mathrm{Db}$ \\
\hline
\end{tabular}

Note. Age of faulted or fractured lithology: $\mathrm{Tr}=$ Triassic; $\mathrm{J}=$ Jurassic; $\mathrm{K}=$ Cretaceous; $\mathrm{Q}=$ Quaternary. Kinematic indicator: TLT $=$ Tilt of speleothem growth axis; FR = Fractures; FSL = Fault slip lineations. T/Trend and plunge of extension axis. Tectonic regime: $\mathrm{N}=$ normal; $\mathrm{SS}=$ strike slip; $\mathrm{N} \_\mathrm{SS}=$ normal-oblique; $\mathrm{SS} \_\mathrm{N}=$ oblique-normal; tectonic regime undetermined for fractures. Deformation phase $\mathrm{Da}$ and $\mathrm{Db}$ discussed in text.

Geometric measurements were carried over a wide range of shapes on $\sim 250$ samples, both intact and deformed (Table S1 in the supporting information S1). For each measured speleothem, we recorded the length and the average diameter. For stalagmites, we also recorded the diameter at the narrowest section (neck), when present, which is commonly close to their base. Because the stalagmite neck is characterized by a change in orientation of $\mathrm{C}$ axes of calcite crystals from horizontal at the base to vertical above (P. Forti, personal communication, 1999), it represents the weakest section and the area of possible breakage during seismic shaking (Lacave et al., 2004). For broken speleothems, we recorded the length of the fallen section and of the standing stump.

We measured orientation and kinematics of brittle structures indicative of cave damage and speleothem deformation (Table 1). These include high-angle fractures and striated faults developed within both bedrock and concretions (Figures $4 \mathrm{c}$ and $4 \mathrm{~g}$ ), as well as low-angle slip surfaces (Figures $4 \mathrm{e}$ and $4 \mathrm{f}$ ). We also documented anomalies in speleothem growth axis by measuring the tilt direction (Figure 4d). Structural data (faults slip lineations and fractures) were also collected in bedrock outcrops nearby the cavities.

\subsection{Speleothem Dating}

We selected both pre-event and post-event laminae from speleoseismites in order to place age constraints on speleoseismic events. The laminae immediately below and above a breakage or an unconformity (e.g., Figures $4 \mathrm{~b}$ and $4 \mathrm{~d}$ ), indicative of fracturing, tilting, or collapse of a speleothem, are defined as preevent (or precontact) and postevent layers, respectively, and their dating brackets the speleoseismic event age (Becker et al., 2012; Kagan, 2012; Kagan et al., 2005). For fallen speleothems, their youngest layer before collapse and the base of an intact stalagmite grown upon them represent the pre-event and post-event layer, respectively.

We also dated bases and tops of intact speleothems from Morano and Serra del Gufo caves. In case a sampled speleothem showed active growth (modern speleothem), only dating of the base was necessary to define the growth rate. Although this choice assumes a continuous speleothem growth, the relatively young age of the sampled concretions minimizes assumption uncertainty. The estimated growth rates were then used to estimate the age of undated and unbroken speleothems.

\subsubsection{U/Th Dating}

The ages of eight selected samples from Serra del Gufo and Morano caves were determined by U-series decay $\left({ }^{230} \mathrm{Th} / \mathrm{U}\right)$ and AMS ${ }^{14} \mathrm{C}$ dating at the Laboratoire des Sciences du Climat et de l'Environnement (LSCE) at 
Gif-sur-Yvette, France (Table S2 in the supporting information S1). Field samples were sawed in half to identify the layers for dating. Subsamples were extracted along the growth axis of stalagmites and stalactites using a dental drill with diamond-encrusted blades. The carbonate fragments were crushed in an agate mortar, dissolved in $(\sim 10 \%)$ diluted $\mathrm{HCl}$ and equilibrated with a mixed ${ }^{236} \mathrm{U}_{-}{ }^{233} \mathrm{U}^{229} \mathrm{Th}$ spike that was calibrated against a Harwell Uraninite solution (HU-1) assumed to be at secular equilibrium. The solutions were evaporated to dryness at $70{ }^{\circ} \mathrm{C}$ and redissolved in $3 \mathrm{~N} \mathrm{HNO}_{3}$. Uranium and thorium were isolated from the other major and trace elements of the carbonate matrix and purified using Eichrom UTEVA and prefilter resins. The isotopes of uranium and thorium were analyzed by solution using a Thermo Scientific ${ }^{\mathrm{TM}}$ NeptunePlus multicollector inductively coupled plasma mass spectrometer fitted with an ARIDUS II desolvating system (full details of the analytical method are reported in Pons-Branchu et al., 2014). Based on the measured atomic ratios, the U/Th ages (Table S2) were calculated through iterative age estimation (Ludwig \& Titterington, 1994), using the half-lives of Cheng et al. (2013) and Jaffey et al. (1971). An initial ${ }^{230} \mathrm{Th} /$ ${ }^{232} \mathrm{Th}$ activity ratio of $2.96 \pm 0.1$ was used for correction of the nonradiogenic, detrital ${ }^{230} \mathrm{Th}$ fraction. This value is the ${ }^{230} \mathrm{Th} /{ }^{232} \mathrm{Th}$ ratio obtained from the analysis of an active speleothem from the Serra del Gufo Cave.

\subsection{Radiocarbon Dating}

Samples from speleothems were ${ }^{14} \mathrm{C}$ dated at the Laboratorio di Fisica of the University of Rome La Sapienza, at the Woods Hole Oceanographic Institution Radiocarbon Laboratory (USA), and at LSCE.

The ages of 23 selected samples from all the Pollino caves were determined by bulk ${ }^{14} \mathrm{C}$ at the Laboratorio di Fisica of the University of Rome La Sapienza during 1996-2000 (Improta et al., 1997; Table S4 in the supporting information S1). For each sample, $3 \mathrm{~g}$ of material was mechanically crumbled and then transformed in benzene following the experimental procedure reported in Belluomini et al. (1978). Radiometric analysis was performed using liquid scintillator counters (Alessio et al., 1976; Brzosko et al., 1986). Because the laboratory ceased its dating activity in 2000, further analytical information are missing.

Samples SA7(8) and SA7(9) were AMS ${ }^{14} \mathrm{C}$ dated at the Woods Hole Oceanographic Institution Radiocarbon Laboratory, USA (Table S4 in the supporting information S1), in 1999.

At LSCE, the carbonate powder of four samples from San Paolo branch of Morano Cave, dated by U/Th, was also analyzed for radiocarbon using a Mini Carbon Dating System (ECHoMICADAS). Prior to analysis, the samples were converted to $\mathrm{CO}_{2}$ in a semiautomated carbonate vacuum line (Tisnérat-Laborde et al., 2001) and then reduced to graphite at the Laboratory of Geosciences Paris Saclay. Radiocarbon results are reported as conventional ${ }^{14} \mathrm{C}$ ages in year BP (Reimer et al., 2004; Stuiver \& Polach, 1977) and as Fraction modern corresponding to the deviation of the ${ }^{14} \mathrm{C} /{ }^{12} \mathrm{C}$ ratio of the sample activity from standard activity measured in the same year, with both activities background corrected and $\delta^{13} \mathrm{C}$ normalized (Table S3 in the supporting information S1). The aim was to calculate the "dead carbon proportion" (DCP) from paired U/Th and ${ }^{14} \mathrm{C}$ ages, which was used then to correct the ${ }^{14} \mathrm{C}$ ages obtained from the other samples. In fact, the meteoric drip water from which speleothem calcium carbonate is precipitated contains carbon derived from the equilibration with atmospheric $\mathrm{CO}_{2}$ but also carbon from the equilibration with the soil $\mathrm{CO}_{2}$ and the radiocarbon-free "dead carbon" from the bedrock. Therefore, the ${ }^{14} \mathrm{C}$ of the speleothems is often offset from the contemporaneous atmospheric ${ }^{14} \mathrm{C}$, and this offset is referred as the DCP, which is the percentage of dead carbon incorporated in the speleothem at the time of formation.

We calculated the DCP from paired U/Th and ${ }^{14} \mathrm{C}$ ages following Genty and Massault (1997): DC[1 $\left.\left(\mathrm{a}^{14} \mathrm{C}_{\text {init }} / \mathrm{a}^{14} \mathrm{C}_{\text {atm.init }}\right)\right] \times 100$, where $\mathrm{a}^{14} \mathrm{C}_{\text {init }}$ is the initial ${ }^{14} \mathrm{C}$ activity of the carbonate and $\mathrm{a}^{14} \mathrm{C}_{\text {atm.init }}$ is the atmospheric ${ }^{14} \mathrm{C}$ activity at the time of carbonate deposition (Table S3 in the supporting information S1). DCP-calculated values are low and range between $2.5 \%$ and $9.8 \%$ for the studied samples. Since DCP can vary as a response of climate oscillations (e.g., increase or decrease in precipitation; Noronha et al., 2014), we tested the effect of a variable amount of DCP on the DCP-corrected ${ }^{14} \mathrm{C}$ ages (as done for instance by Sanchidrián et al., 2017): we calculated the corrected ages for the 25 samples with ${ }^{14} \mathrm{C}$ ages alone, using DCP values of $5 \%$ and $20 \%$ (Table S4): After correcting for DCP, the ${ }^{14} \mathrm{C}$ values were calibrated using Oxcal 4.2 (Bronk Ramsey, 2013) and the IntCal13 curve (Reimer et al., 2013). This translates to a difference between DCP-corrected and DCP-uncorrected ${ }^{14} \mathrm{C}$ ages of approximately $20 \%$ and less than $5 \%$ for Holocene and Late Pleistocene samples, respectively, which is not critical for speleoseismic events interpretation. 


\subsection{Numerical and Hazard Modeling}

A numerical modeling was performed to estimate the values of the horizontal ground acceleration required to failure the speleothems. Following the approach proposed by Gribovszki et al. (2018), we used a finite element method (FEM) running on the SAP200 software, starting from the detailed geometry of the speleothem and its mechanical properties derived from laboratory tests (Colella et al., 2017). Supporting information S1 and Text S1 delivers details of the FEM used in this study. Finally, by establishing the age of intact speleothems, we used the model horizontal ground acceleration values to determine a threshold value of ground motion that has not been exceeded during the speleothem lifetime.

In order to evaluate the seismic hazard at the five cavities, we defined a seismogenic source model and, using three different ground motion prediction equations (GMPEs, Bindi et al., 2011; Cauzzi et al., 2015; Bindi et al., 2014) and a widely used seismic hazard code (OpenQuake Engine; Pagani et al., 2014), we calculated the probabilistic hazard curves at the study sites. The GMPEs have been combined into a logic tree with the weights equal to $0.39,0.27$, and 0.34 , respectively, following the selection and ranking for the new Italian hazard map (Lanzano et al., 2017). We also carried out a deaggregation analysis to evaluate the contribution of each seismogenic source to the seismic hazard at each cave.

Finally, we compared the seismic hazard curves of each seismogenic source at individual caves with the vulnerability and inferred ages of unbroken speleothems to test the robustness of our probabilistic seismic hazard assessment.

\section{Results}

\subsection{Morphological and Structural Observations in the Pollino Caves}

The studied caves lie along a $\sim 18-\mathrm{km}$ distance on the southern flank of the Pollino Range. Four of them (Serra del Gufo, Damale, S. Angelo Superiore, and Rüah) are located in the footwall of the CF, and one (Morano) rests in the hanging wall. With respect to the EPF, two caves (Serra del Gufo, Damale) are uplifted in its footwall, and the remaining two (S. Angelo Superiore and Rüah) reside in the hanging wall (Figure 3).

These are relict cavities with a limited (few hundreds of meters up to $1 \mathrm{~km}$ ) and predominantly horizontal development and have entrances at elevation between 360 and $680 \mathrm{~m}$ above sea level (a.s.l.; Figure 3). All the caves, with the exception of one section of Morano (the Ramo del Fiume section) show vadose concretions superposed on well-developed phreatic morphologies (Ferranti \& Maschio, 2007). Their origin ensues from the rising of thermal waters, which mineralize by passing through the Neogene formations of the Sibari Plain (hypogenic outflow caves: Galdenzi, 1997). Because the cavities are presently preserved in limited carbonate blocks (Morano and S. Angelo Superiore), speleogenesis occurred when these blocks still had a physical connection with the main mountain range, before slip on the PL separated them. Based on available stratigraphic data (Bousquet \& Gueremy, 1969; Russo \& Schiattarella, 1992), the age interval of the ancient phreatic network is attributed to the Emilian ( 1.5-1.0 Ma). At this time, the Castrovillari Basin formed at the foot of the Pollino massif due to slip along the PL, creating a hydrologic gradient toward the south (Piana di Sibari) and the east (Ionian Sea). Disarticulation of the karst network occurred during and soon after the Sicilian (late part of the Early Pleistocene, $1.0-0.8 \mathrm{Ma}$ ), when deposition in the Castrovillari Basin waned. The superposed vadose morphologies result from lowering of the karst base level, which derives from a combination of slip on faults and regional uplift of the Calabrian Arc. Commencement of regional uplift in the area is assigned to the early Middle Pleistocene ( 0.6-0.8 Ma; Ferranti et al., 2009; Santoro et al., 2009, 2013) and set the lower age bound for growth of vadose concretions.

Geomorphology and structural analysis of the studied caves are presented for the Cassano, Sellaro and Morano block. Detailed maps with geological features and locations of sampled speleothems are in Figures S1 to S5 in the supporting information S1 (Larocca, 1991). Sketches and pictures of sampled and sawed speleothems for dating spelseoseismite events and growth rates are reported in the supporting information S1 (Text S2).

4.1.1. Cassano Block

The S. Angelo Superiore and Rüah caves develop in Upper Triassic-Liassic dolomites and limestone that floors the isolated hill of Cassano allo Jonio south of the Pollino Range. Low-permeability strata of the Liguride Complex and of Neogene terrigenous sequence surround the carbonate block, which is limited 


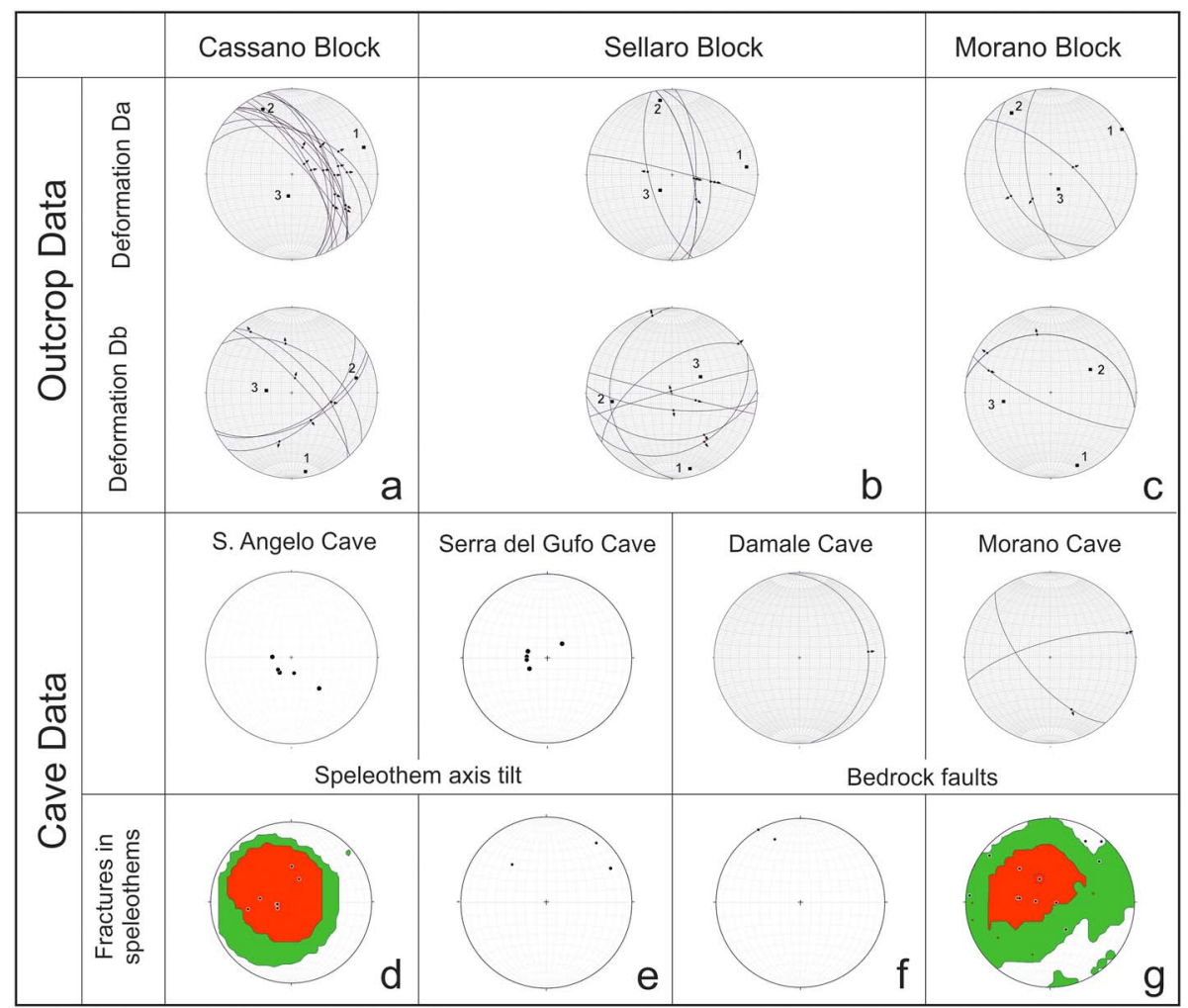

Figure 5. Structural data from inside and outside the studied Pollino caves: (a-c) projection of faults and fault slip lineations collected at individual measurement sites outside the caves, distinguished according to deformation phase Da and $\mathrm{Db}$. Arrows on great circles indicate motion of hanging wall block; filled squares are tension and compression axis related to local slip; numbers 1, 2, and 3 are linked Bingham extension, null, and compression axis, respectively; (d-g) data collected within each cave: (top), speleothem axis tilt directions and bedrock faults; (bottom) contoured fractures in speleothems and concretions (contour interval $=2$ sigma; significance level $=3$; counting area $=42.86 \%$ of net area); fracture projections in (e) and (f) lack contours because of the limited data number.

by NW-SE and NE-SW striking faults on all sides (Figure 3). Structural data collected outside the caves confirm these trends and reveal that the main NW to NNW-trending fault bounding the block on the eastern side experienced motion during two distinct displacement fields, the deformation phase Da and the deformation phase $\mathrm{Db}$ (Figures 5a-5c). Observations of striations superpositions are not adequate to establish the relative chronology between the two displacement fields. During $\mathrm{Da}$ and $\mathrm{Db}$, the fault was active as normal to right oblique and left oblique, respectively. Inversion of fault slip lineations indicates that $\mathrm{Da}$ and $\mathrm{Db}$ occurred with an ENE-WSW trending and a NNW-SSE trending extension axis, respectively (Figure 3). During Db, NE-SW striking normal faults were also active.

The S. Angelo Superiore Cave is the uppermost part of a $\sim 2-\mathrm{km}$-long complex whose entrance is at $\sim 450 \mathrm{~m}$ a.s.l. along the steep northeastern side, at the intersection of the main NW-SE striking border fault and of an ENE-WSW striking fault that cuts the block. The cave consists of several subparallel horizontal passages at slightly different elevations, indicative of minor oscillations of the base level, which intersect a large room (Figure S1). The trend of galleries aligns in the ENE-WSW direction, parallel to the fault that dissects the block and to the measured secondary faults.

Displacements of up to $10 \mathrm{~cm}$ of the cave walls and of mammary concretions are observed along ENE to ESE striking faults, as well as offsets of columns along NNW-SSE and subordinately WNW-ESE striking lowangle slip surfaces (Figures 4e and 4f). These latter displacements are indicative of both ENE- and SSEdirected motion (Figure 5d) and thus agree with deformation phases $\mathrm{Da}$ and $\mathrm{Db}$, respectively. In addition, the growth axis of speleothems is tilted from the vertical and their distribution forms an $\sim$ NW-SE trending girdle (Figure 5d). Because sedimentary beds dip to the south (Figure S1), dispersion of growth axis due to interlayer slips can be ruled out and rather suggests deformation of the whole block. Similar deformations 
are observed in the nearby Rüah Cave, which has a NNE-SSW linear trend that follows the strike of a normal fault exposed on one side of the cavity (Figure S2).

4.1.2. Sellaro Block

The Damale and nearby Serra del Gufo caves are located on the southern slope of the M. Sellaro ridge, a folded monocline that forms the easternmost carbonate outcrop of the Pollino Range (Figure 3). Structural analysis outside the cavities reveals the existence of two populations of faults, which, based on observations at the Cassano block, were likely active under a WSW-ENE (Da) and an NNW-SSE (Db) extension regime, respectively (Figure 5b).

The morphology of passages at Damale Cave, with regular subcircular sections and decimeter-scale side scallops and emorsion mufflers on the roof, points to the past existence of an important phreatic flow. The cave, whose entrance is at $360 \mathrm{~m}$ a.s.l., has a WNW-ESE trend (Figure S3) that reflects the strike of the M. Sellaro bordering fault (Figure 3). An N-S striking normal fault mapped in the cavity (Figures 4c and 5f) suggests it developed during Da. In addition, ENE-WSW striking open joints within concretions indicate a NNW-SSE extension (Figure 5f), suggesting that $\mathrm{Db}$ phase affected the vadose stage as well.

The $\sim 1-\mathrm{km}$-long Serra del Gufo is a relict cavity containing inclined passages that rise toward the surface. The dip of the limestone beds controls the cave pattern, which elongates NNE-SSW (Figure S4), although in the deeper part (not shown in Figures S1 to S5 in the supporting information S1), it also has NW-SE trending sections consistent with the strike of the bordering fault. Phreatic tubes are common; however, vault collapses and carbonate concretions (locally gypsum) have obliterated many of the original features. The entrance is at $\sim 500 \mathrm{~m}$ a.s.l., an elevation that possibly represents a former base level (Galdenzi, 1997) and broadly coincides with that of alluvial gravel terraces capping the Castrovillari basin. Our observations in the first $\sim 200 \mathrm{~m}$ of the cave showed many standing speleothems, often of very large dimensions and few occasional collapses of up to meter-scale samples (Figure 4b). The growth axis of small columns is deflected of few centimeters mostly toward the W (Figure 5e). Fractures with both NW-SE and NE-SW strike are present, indicating the effect of deformation stages $\mathrm{Da}$ and $\mathrm{Db}$, respectively (Figure 5e).

4.1.3. Morano Block

The Morano Cave developed north of Morano Calabro village within an isolated block of Jurassic dolomite and cherty limestone (Figure 3). The cave is made of anastomosing passages elongated NW-ES parallel to a fault zone, locally exposed inside, which controlled the speleogenesis (Figure S5). Structural analysis both outside (Figure 5c) and within (Figure 5g) the cavity suggests a left-trastensional fault associated to secondary NNE-SSW striking right-oblique faults. However, evidence of normal motion on the NW-SE striking faults is also present outside the cavity (Figure $5 \mathrm{c}$ ), supporting the notion that both Da- and Db-controlled cave development.

The cave passages are set at two levels. The higher level (S. Paolo branch) at $\sim 660 \mathrm{~m}$ a.s.l. shows both fossil and active vadose concretions, the lower one (Ramo del Fiume branch) at $\sim 630 \mathrm{~m}$ a.s.l. is close to the groundwater level and is seasonally impassable (Figure S5). We carried observations and sampling in the first 100 $\mathrm{m}$ of both branches of the cavity. Several joints with both NE-SW and NW-SE strike cut the concretions (Figures $4 \mathrm{~g}$ and $5 \mathrm{~g}$ ), indicative of both $\mathrm{Da}$ and $\mathrm{Db}$ deformations. In addition, small columns or stalactitestalagmite couplets are offset toward the west of maximum $5 \mathrm{~cm}$. Overall, structural analysis suggests that a secondary left-transtensional segment of the main Pollino Fault controlled cave development and was still active during growth of concretions (Figure 3). Although some fallen blocks are occasionally present, intact active concretions with slender geometry are abundant in the cave.

4.1.4. Age of Deformation Summary

Although we were not able to define the relative chronology of $\mathrm{Da}$ and $\mathrm{Db}$, they were certainly active during the phase of disarticulation of the hypogeum karst network, which occurred during the Sicilian $(\sim 1.0-0.8$ $\mathrm{Ma})$. In addition, the observation that faults and fractures related to both $\mathrm{Da}$ and $\mathrm{Db}$ affect vadose concretions, which largely developed after commencement of regional uplift $(\sim 0.8-0.6 \mathrm{Ma})$, document their Middle-Late Pleistocene activity. Deformation went on during the last $\sim 45 \mathrm{ka}$ as illustrated by speleoseismic events described in the following section.

\subsection{Radiometric Age Constraints on Speleoseismic Events}

The U/Th and ${ }^{14} \mathrm{C}$ dating provide constraints on the age of speleoseismic events (Figure 6 and Table 2; more detailed information on sampled speleothems are in Text S2 in the supporting information S1). The event 


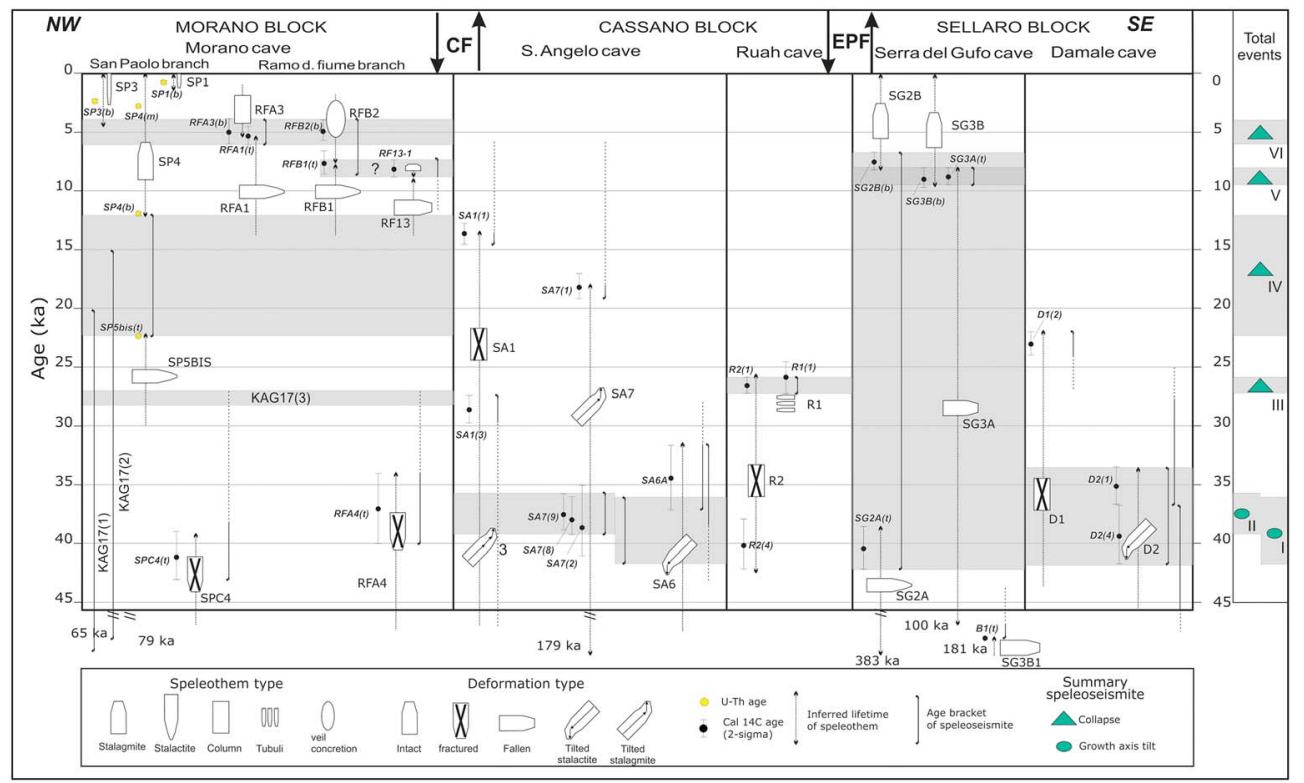

Figure 6. Chronological scheme of the speleoseismic events in the Pollino area by crossing individual events found in the studied caves. The speleothem type and the deformation mode are shown for each sample. The gray bands indicate events constrained by both preevent and postevent layers; width of the band indicates the bracketed event age. Event bracketed with dotted line indicates uncertainty in the preevent or postevent age. Events much older than 45 ka are indicated beneath border of figure. KAG17(1), KAG17(2), and KAG17(3) are speleoseismic events reported by Kagan et al. (2017) for the Morano Cave. $\mathrm{CF}=$ Castrovillari Fault; EPF = Eastern Pollino Fault.

ages established from samples dated by ${ }^{14} \mathrm{C}$ (Table 2) have been calculated using the mean preferred calibrate ages (Table S4).

Within the Morano block, located in the hanging wall of the CF, and specifically in the S. Paolo branch of the Morano Cave, a speleoseismite event is bracketed between the $~ 22$-ka-old tip layer of stalactite SP5bis and the 12-ka-old base layer of stalagmite SP4, grown over the collapsed ceiling hosting the stalactite (see Text S2). Further evidence of deformation is provided by SPC4, a stalactite whose tip broke, and ${ }^{14} \mathrm{C}$ dating of the layer grown over the unconformity constrains the event to $<39-43 \mathrm{ka}$.

Within the Ramo del Fiume branch, we obtained ages for two pairs of pre-event and post-event layers (RFA1-RFA3 and RFB1-RFB2, respectively) from two fallen spelothems and from the intact overgrown (Figure 6). These ages tightly constrain two overlapping events, which are likely to be a single event at 3.9-6.0 ka. For stalagmite RF13, we have only the age of the postevent layer, which is 7.3-8.8 ka. However, the dated postevent concretion likely developed immediately following the fall of RF13 (see Text S2). Finally, the ${ }^{14} \mathrm{C}$ dating of a layer that seals fractures within stalagmite RFA4 documents ages of the fractures are older than $~ 34-40 \mathrm{ka}$.

Speleoseismic deformations in the Cassano block, which forms the footwall of the CF, are constrained by dating pre-event and post-event layers from Rüah and S. Angelo Superiore caves. In the latter cavity, we sampled column SA1, which is cut by low-angle slip surfaces with minor displacement that did not break the speleothem (Text S2). Dating of the outermost layer SA1(1) documents that low-angle fractures and slip occurred after 12.7-14.5 ka. We also dated an internal layer SA1(3), which fills fractures within the stalagmite and seals three different tilt episodes of the stalagmite growth axis before the columnar stage. The obtained age sets tilting and fracturing prior to $27-30 \mathrm{ka}$, although we are not able to bracket relative ages of the tilting stages (Figure 6 and Table 2). Similarly, stalagmite SA7 exhibits three variations of the direction of the growth axis that highlight two episodes of tilting prior to the final one, that likely halted concretion. Within the stalagmite, the two speleoseismic contacts related to tilting are marked by unconformities and changes in the cement habitus from well layered to sparry (Figures $4 \mathrm{f}$ and $4 \mathrm{~g}$ and Text S2). Dating of preevent and postevent layers documents that these two events occurred close in time and their uncertainties overlap between $\sim 36$ and $42 \mathrm{ka}$ (Table 2). The final tilt occurred after $\sim 17-19 \mathrm{ka}$. Stalactite SA6 overhangs 
Table 2

Age Constraints on Speleoseismic Events From U-Th and ${ }^{14} \mathrm{C}$ Dating Results

\begin{tabular}{|c|c|c|c|c|c|c|c|c|c|}
\hline Block & Cave & Speleothem type & $\begin{array}{l}\text { Speleothem } \\
\text { Id }\end{array}$ & $\begin{array}{l}\text { Sample } \\
\text { Id }\end{array}$ & Significance & $\begin{array}{l}\text { Dating } \\
\text { method }\end{array}$ & $\begin{array}{c}\text { Median } \\
\text { probability } \\
\text { (BP) }\end{array}$ & $\begin{array}{l}\text { Calibrated age } \\
\text { (BP, 2-s range) }\end{array}$ & $\begin{array}{l}\text { Speleoseismic } \\
\text { event age (BP) }\end{array}$ \\
\hline \multirow[t]{10}{*}{ Sellaro } & \multirow[t]{5}{*}{ Serra del Gufo } & Intact STLGMT & SG3B & SG3B(b) & Post-event & ${ }^{14} \mathrm{C}$ & 8,973 & $8,016-9,698$ & \multirow[t]{2}{*}{$8,016-9,527$} \\
\hline & & Fallen STLGMT & SG3A & SG3A(t) & Preevent & ${ }^{14} \mathrm{C}$ & 8,754 & $7,850-9,527$ & \\
\hline & & Intact STLGM & SG2B & $\mathrm{SG} 2 \mathrm{~B}(\mathrm{~b})$ & Postevent & ${ }^{14} \mathrm{C}$ & 7,519 & $6,663-8,172$ & \multirow[t]{2}{*}{$6,663-42,198$} \\
\hline & & Fallen STLCT & SG2A & $\mathrm{SG} 2 \mathrm{~A}(\mathrm{t})$ & Preevent & ${ }^{14} \mathrm{C}$ & 40,427 & $38,526-42,198$ & \\
\hline & & Fallen STLGM & SGRB1 & $\mathrm{B} 1(\mathrm{t})$ & Preevent & U-Th & 180,818 & $180,078-181,558$ & $<180,078-181,558$ \\
\hline & \multirow[t]{5}{*}{ Damale } & Fractured column & D1 & $\mathrm{D} 1(2)$ & Postevent & ${ }^{14} \mathrm{C}$ & 23,191 & $22,040-24,135$ & $>22,040-24,135$ \\
\hline & & Tilted STLCT & D2 & $\mathrm{D} 2(1)$ & Preevent III & ${ }^{14} \mathrm{C}$ & 35,138 & $33,434-36,730$ & $<33,434-36,730$ \\
\hline & & & & $\mathrm{D} 2(1)$ & Postevent II & ${ }^{14} \mathrm{C}$ & 35,138 & $33,434-36,730$ & $33,434-41,651$ \\
\hline & & & & $\mathrm{D} 2(4)$ & Preevent II & ${ }^{14} \mathrm{C}$ & 39,387 & $36,795-41,651$ & \\
\hline & & & & $\mathrm{D} 2(4)$ & Postevent I & ${ }^{14} \mathrm{C}$ & 39,387 & $36,795-41,651$ & $>36,795-41,651$ \\
\hline \multirow[t]{11}{*}{ Cassano } & \multirow[t]{2}{*}{ Ruah } & Fractured column & $\mathrm{R} 2$ & $\mathrm{R} 2(1)$ & Postevent & ${ }^{14} \mathrm{C}$ & 26,379 & $25,324-27,339$ & \multirow[t]{2}{*}{$25,324-26,781$} \\
\hline & & Fallen tubules & $\mathrm{R} 1$ & $\mathrm{R} 1(1)$ & Preevent & ${ }^{14} \mathrm{C}$ & 25,786 & $24,518-26,781$ & \\
\hline & \multirow[t]{9}{*}{ S. Angelo Superiore } & \multirow[t]{2}{*}{$\begin{array}{l}\text { Fractured and offset } \\
\text { column }\end{array}$} & \multirow[t]{2}{*}{ SA1 } & SA1(1) & Preevent & ${ }^{14} \mathrm{C}$ & 13,632 & $12,725-14,534$ & $<12,725-14,534$ \\
\hline & & & & SA1(3) & Postevent & ${ }^{14} \mathrm{C}$ & 28,564 & $27,400-29,735$ & $>27,400-29,735$ \\
\hline & & \multirow[t]{2}{*}{ Tilted STLCT } & \multirow[t]{2}{*}{ SA6 } & \multirow[t]{2}{*}{ SA6A } & Preevent II & ${ }^{14} \mathrm{C}$ & 34,480 & $31,566-37,132$ & $<31,566-37,132$ \\
\hline & & & & & Postevent I & ${ }^{14} \mathrm{C}$ & 34,480 & $31,566-37,132$ & $>31,566-37,132$ \\
\hline & & \multirow[t]{5}{*}{ Tilted STLGMT } & \multirow[t]{5}{*}{ SA7 } & SA7(1) & Preevent III & ${ }^{14} \mathrm{C}$ & 18,184 & $16,971-19,124$ & $<16,971-19,124$ \\
\hline & & & & SA7(9) & Postevent II & $\begin{array}{l}\mathrm{AMS} \\
{ }^{14} \mathrm{C}\end{array}$ & 37,491 & $35,799-38,937$ & \multirow[t]{2}{*}{$35,799-39,214$} \\
\hline & & & & SA7(8) & Preevent II & $\begin{array}{l}\mathrm{AMS} \\
{ }^{14} \mathrm{C}\end{array}$ & 38,045 & $36,122-39,214$ & \\
\hline & & & & & Postevent I & & 38,045 & $36,122-39,214$ & $36,122-41,788$ \\
\hline & & & & SA7(2) & Preevent I & ${ }^{14} \mathrm{C}$ & 38,695 & $34,932-41,788$ & \\
\hline \multirow[t]{9}{*}{ Morano } & \multirow[t]{3}{*}{ S. Paolo } & Intact STLGMT & SP4 & SP4(b) & Postevent & U-Th & 11,857 & $11,640-12,077$ & \multirow[t]{2}{*}{$11,640-22,082$} \\
\hline & & Fallen STLCT & SP5bis & SP5bis(t) & Preevent & U-Th & 21,972 & $21,860-22,082$ & \\
\hline & & Fractured STLCT & SPC4 & $\mathrm{SPC} 4(\mathrm{t})$ & Preevent & ${ }^{14} \mathrm{C}$ & 40,984 & $38,946-42,862$ & $<38,946-42,862$ \\
\hline & \multirow[t]{6}{*}{ Ramo del Fiume } & Intact STLGMT & RFA3 & RFA3(b) & Postevent & ${ }^{14} \mathrm{C}$ & 5,067 & $3,922-5,893$ & \multirow{2}{*}{$3,922-6,025$} \\
\hline & & Fallen STLCT & RFA1 & RFA1(t) & Preevent & ${ }^{14} \mathrm{C}$ & 5,303 & $4,281-6,025$ & \\
\hline & & Intact veil & RFB2 & RFB2(b) & Postevent & ${ }^{14} \mathrm{C}$ & 4,908 & $3,829-5,727$ & \multirow[t]{2}{*}{$3,829-8,587$} \\
\hline & & Fallen STLCT & RFB1 & $\mathrm{RFB1}(\mathrm{t})$ & Preevent & ${ }^{14} \mathrm{C}$ & 7,596 & $6,394-8,587$ & \\
\hline & & Fallen STLGMT & RF13 & RF13-1 & Postevent & ${ }^{14} \mathrm{C}$ & 8,129 & $7,308-8,790$ & $>7,308-8,790$ \\
\hline & & Fractured STLGMT & RFA4 & RFA4(t) & Postevent & ${ }^{14} \mathrm{C}$ & 37,248 & $34,146-40,158$ & $>34,146-40,158$ \\
\hline
\end{tabular}

Note. STLGMT $=$ stalagmite; STLCT $=$ stalactite.

a stump from which an older stalagmite or column has been displaced. The stalactite experienced a tilt toward the NW. Dating of the older layer of SA6 yields a 31- to 38-ka age limit between deformation that originated the stump and younger tilt of the stalactite (Figure 6 and Table 2).

At Rüah, we studied column R2 that started growing at 38-42 ka (Table S4). The youngest layer of the column grew upon fallen soda straws (thin tube stalactites; four of them are grouped in sample R1). The ages of the outermost layer of R2 and of the soda straws overlap within uncertainty (Table S2), tightly constraining a speleoseismite event at 25.2-26.7 ka (Figure 6 and Table 2).

Within the Sellaro block, which forms the footwall of the EPF, we obtained ${ }^{14} \mathrm{C}$ ages of pre-event and postevent layers from two speleoseismic couples at Serra del Gufo Cave (Figure 6 and Table 2). The age bracket for collapse of stalactite SG2A (Figure $4 \mathrm{~b}$ and Text S2) is wide ( 42-7 ka), but the nearby fall of stalactite SG3A is tightly constrained at $\sim 8-9.5 \mathrm{ka}$. Finally, the top of a collapsed stalagmite (SGRB1, Text S2) provides a post-181-ka age for the deformation. Because the stalagmite could have stopped growing long before the present, the fall event is not necessarily so old.

At Damale Cave, we obtained a $\sim 23-\mathrm{ka}$ age for the most recent concretion that seals conjugate fractures within <1-m-tall column D1 (Figure 6 and Table 2). We also dated changes in growth axis within stalactite D2, which however remained in connection within the underlying, paired stalagmite. The sawed section of 
Table 3

Speleothem Age and Growth Rates From U-Th Dating Results

\begin{tabular}{|c|c|c|c|c|c|c|c|c|}
\hline Cave & $\begin{array}{l}\text { Speleothem } \\
\text { type }\end{array}$ & $\begin{array}{l}\text { Speleothem } \\
\text { ID }\end{array}$ & $\begin{array}{l}\text { Sample } \\
\text { ID }^{A}\end{array}$ & $\begin{array}{l}\text { Dating } \\
\text { method }\end{array}$ & $\begin{array}{c}\text { Median } \\
\text { probability (ka BP) }\end{array}$ & $\begin{array}{c}\text { Samples } \\
\text { distance }(\mathrm{cm})^{\mathrm{b}}\end{array}$ & $\begin{array}{l}\text { Speleothem } \\
\text { length }(\mathrm{cm})\end{array}$ & $\begin{array}{l}\text { Growth } \\
\text { rate }(\mathrm{cm} / \mathrm{ka})\end{array}$ \\
\hline \multirow[t]{3}{*}{ Serra del Gufo } & STLGM & SGRB1 & $\mathrm{B} 1(\mathrm{t})$ & U-Th & 180,818 & & 218 & $\geq 0.4-0.5^{\mathrm{c}}$ \\
\hline & STLGM & SGB2 & B2(b) & U-Th & 374,503 & 14 & 253 & $\geq 0.3-0.4^{\mathrm{d}}$ \\
\hline & & & $\mathrm{B} 2(\mathrm{t})$ & U-Th & 251,068 & & & \\
\hline \multirow[t]{7}{*}{ Morano } & STLGMT & SP4 & $\mathrm{SP} 4(\mathrm{t})$ & - & $0^{\mathrm{e}}$ & 2.7 & & 1.0 \\
\hline & & & $\mathrm{SP} 4(\mathrm{~m})$ & U-Th & 2,762 & 11 & & 1.2 \\
\hline & & & SP4(b) & U-Th & 11,857 & & & \\
\hline & STLT & SP1 & $\mathrm{SP} 1(\mathrm{t})$ & - & $0^{\mathrm{e}}$ & 0.7 & & 1.2 \\
\hline & & & $\mathrm{SP} 1(\mathrm{~m})$ & U-Th & 0,614 & & & \\
\hline & STLT & SP3 & $\mathrm{SP} 3(\mathrm{t})$ & - & $0^{\mathrm{e}}$ & 2.2 & & 1.0 \\
\hline & & & $\mathrm{SP} 3(\mathrm{~m})$ & U-Th & 2,241 & & & \\
\hline
\end{tabular}

Note. STLGM = stalagmite; STLCT $=$ stalactite.

$\mathrm{a}(\mathrm{b})=$ base part $(\mathrm{m})=$ median part; $(\mathrm{t})=$ top part. $\quad{ }^{\mathrm{b}}$ Distance between dated layers used to calculate incremental growth rate. $\quad{ }^{\mathrm{c}}$ Computed by assuming a 0.78 to 0.60 -Ma age for the base based on the regional estimate of onset of concretion. The growth rate computed on the specimen is $0.1 \mathrm{~cm} / \mathrm{ka}$. The estimate for the whole speleothem derives by assuming a 0.78 - to 0.60 -Ma age for onset of concretion. ${ }^{\mathrm{e}}$ Modern speleothem.

stalactite D2 reveals three different growth axes indicating three deflections, with the younger occurred after 33-37 ka, the intermediate between $\sim 42$ and $33 \mathrm{ka}$, and the oldest one prior to $37-42 \mathrm{ka}$ (Table 2).

\subsection{Speleothem Growth Rates}

$\mathrm{U} / \mathrm{Th}$ ages of relatively undisturbed layers within both standing and fallen speleothems allow estimation of concretion growth rates within caves located in different blocks (Table 3). The computed growth rates derive from both stalagmites, where bottom-up accretion steadily occurs, and stalactites, where accretion proceeds from inside to outside (Figure 7).

We assume for this computation a continuous growth rate. Although we are aware that speleothem growth can be highly irregular in time (e.g., Kagan, 2012; Kagan et al., 2005), most ages using to stipulate ages are

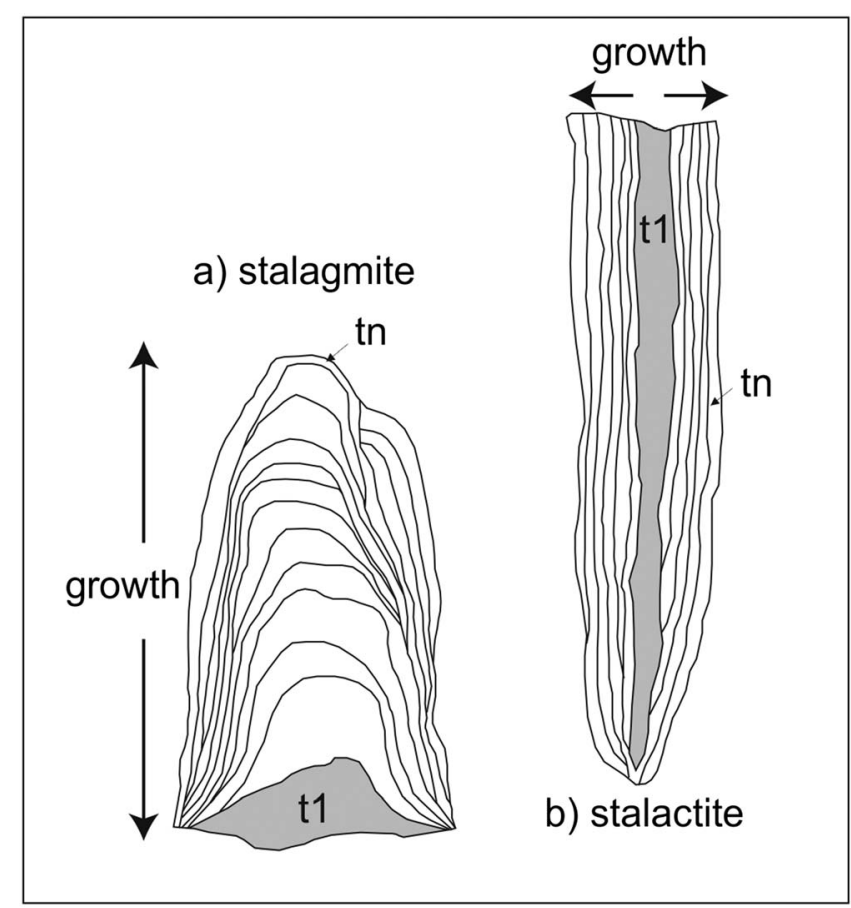

Figure 7. Sketch of growth mode of stalagmites and stalactites. T1 and tn are layers deposited at time steps 1 and $\mathrm{n}$, respectively.
(Late) Holocene (Table 3), which ameliorates errors inherent in the assumption.

At Serra del Gufo, we computed growth rates from stalagmites. For speleothems SGB2 and SGRB1, which are tall (up to $2.5 \mathrm{~m}$, Table 3) old speleothems, lacking information on the age of their base. We forced a 600- to 780-ka age for the initial growth of the concretions based on the inferred age of the transition from phreatic to vadose regime (see section 4.1). By using those estimates, and the U/Th age of $181 \pm 0.7 \mathrm{ka}$ for the uppermost portion of the stalagmite SGRB1 (Text S2), we calculated a minimum growth rate of $\sim 0.4-0.5 \mathrm{~cm} / \mathrm{ka}$. Samples from the topmost $(14 \mathrm{~cm})$ part of the slender and tall stalagmite SGB2 (Text S2) have U/Th ages of 374 $\pm 6 \mathrm{ka}$ (base) and $251 \pm 2 \mathrm{ka}$ (top), corresponding to an average growth rate of $\sim 0.1 \mathrm{~cm} / \mathrm{ka}$ during that time span. Extrapolation of the computed growth rate to the entire SGB2 sample results in a very old (2.3 Ma) age, clearly in contrast with geological age constraints on karst development. Assuming again a 600- to 780-ka age for vadose stage onset, we suggest that pre-380-ka growth rates for this speleothem were at least 0.3-0.4 $\mathrm{cm} / \mathrm{ka}$ (Table 3).

Growth rate estimations for Morano Cave are provided from stalagmite SP4 (Text S2) by ages of the base $(12 \pm 0.2 \mathrm{ka})$ and of a layer near the top $(2.8 \pm 0.1 \mathrm{ka})$ and by the constraint that SP4 was a still-active speleothem when sampled. The growth rate estimations are similar (1.0-1.2 $\mathrm{cm} / \mathrm{ka}$ ). Similarly, U/Th dating of bases of active stalactites SP1 and SP3 (Text S2) provides growth rates of $1.0-1.2 \mathrm{~cm} / \mathrm{ka}$. 


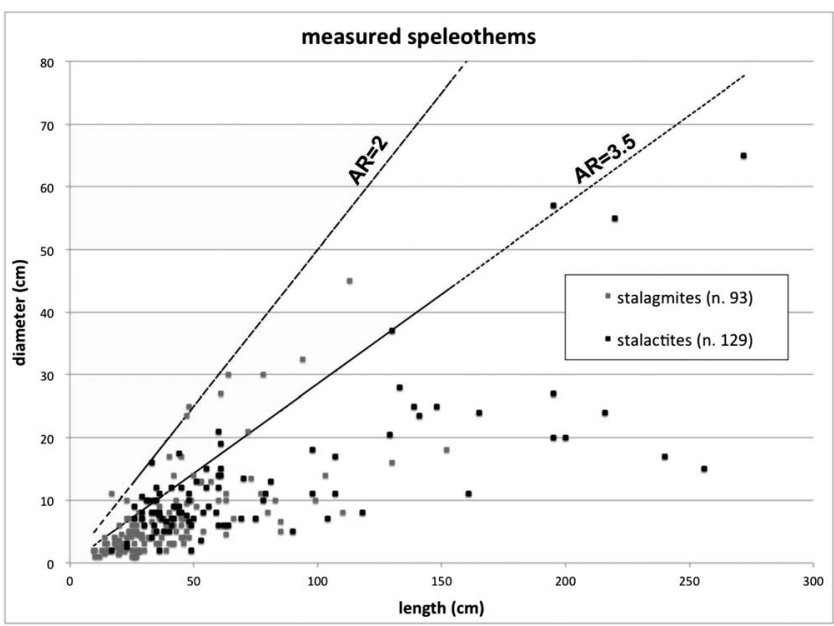

Figure 8. Diameter-length relation for each measured speleothem. The dashed black lines are for an aspect ratio (length/diameter) equals to 2 and 3.5.

\subsection{Intact Speleothems Age and Nonshaking Interval for Morano and Serra del Gufo Caves}

The average growth rates obtained by speleothems dating provide a mean to estimate the age of intact speleothems from all the studied caves, whose geometric parameters have been measured in situ. The major requirement for this computation is that speleothems must be actively growing, and thus the estimated age refers to the present day. Again, we assume a constant growth rate, with assumption uncertainties mitigated by the computed young age of speleothems.

This calculation yields a wide population of recent speleothems of defined age and geometry that can be used for evaluating the speleothem vulnerability to shaking. We limited the computation to relatively vulnerable speleothems, which are the slenderer (length between 10 and $270 \mathrm{~cm}$ and a mean value of $\sim 55 \mathrm{~cm}$; mean diameter value of $\sim 10 \mathrm{~cm}$ ) samples. The selected stalactites from both caves have an aspect ratio $(\mathrm{AR}=$ length/diameter) larger than 3.5, whereas the stalagmites have an AR $>2$ (Table $\mathrm{S} 1$ and Figure 8). We used a growth rate range between 0.3 and 1.2 $\mathrm{cm} / \mathrm{ka}$ that encompasses the range of calculated values (Table 3 ).

For stalagmites that grow upward steadily (Figure 7), the age computation is straightforward and includes the length of the sample and the calculated growth rate. On the contrary, because stalactites start growing rapidly downward, and then more steadily both laterally and vertically, we used the half diameter to compute the age (Figure 7).

Results indicate that 41 unbroken stalactites from S. Paolo branch of the Morano Cave have estimated ages included within the last $5 \mathrm{ka}$. Five stalagmites and stalactites have ages between 22 and $47 \mathrm{ka}$, and one about 3-m-long stalagmite is $360 \mathrm{ka}$ old (Table S1). At Serra del Gufo, the inferred age of the total of 27 unbroken stalactites is between 3 and $9 \mathrm{ka}$. Inferred ages of 33 unbroken stalagmites at Serra del Gufo are older (30-340 ka, Table S8). Out of 51 unbroken speleothems from Damale Cave, 43 stalactites have ages between 0.7 and 9 $\mathrm{ka}$, whereas the age of the eight stalagmites ranges between 48 and $131 \mathrm{ka}$ (Table S1). Finally, at S. Angelo Cave, 16 stalactites and 47 stalagmites have ages between 1.3-10 and 35-188 ka, respectively (Table S1).

The result that stalactites are younger than stalagmites (Figure 9) possibly ensues from their different vulnerability, deriving from the different growth process (Figure 7). Indeed, stalactites have typically a slender geometry than stalagmites of the same age and so are more vulnerable to seismic shaking.

\subsection{Seismogenic Source Model and Seismic Hazard}

We carried out a probabilistic seismic hazard analysis to model the impact of earthquakes generated by faults located in the surroundings of the study area of speleothems within the Pollino caves. Our analysis aimed at defining the total hazard curve for each cave, against which we compared ages of unbroken speleothems, and the peak ground accelerations threshold for those speleothem as derived from the FEM modeling (for more details see Text S1).

We used for the analysis a purportedly built seismogenic source model that integrates the most updated knowledge of active tectonics in the area (see section 2.2 for details). We defined six seismogeneic sources (Figure 2 and Table 4). The two westerns of them (Mercure Source [MS] and Castrovillari Source [CS]) underlie the west-dipping MF and CF normal faults, respectively, with seismogenic thickness of 13-15 $\mathrm{km}$. We did not include in our model a source underlying the WPF, because the fault is considered no longer active along much of its length (Brozzetti et al., 2017). However, trenching on the easternmost part of the WPF documented Holocene events broadly coeval to those found on the CF (Michetti et al., 1997). Following Michetti et al. (1997), we consider this section of the WPF (Figure 3) linked with the CF as part of a single seismogenic source (CS).

The remaining four sources (Eastern Pollino Source [EPS], Satanasso Source [STSS], Amendolara Source [AMS], and Rossano Source [RS]) to the east underlie the north-dipping left-transpressive faults with a deeper $(22 \mathrm{~km})$ seismogenic depth. We used a distance threshold of $\sim 50 \mathrm{~km}$ beyond which we consider the effect 


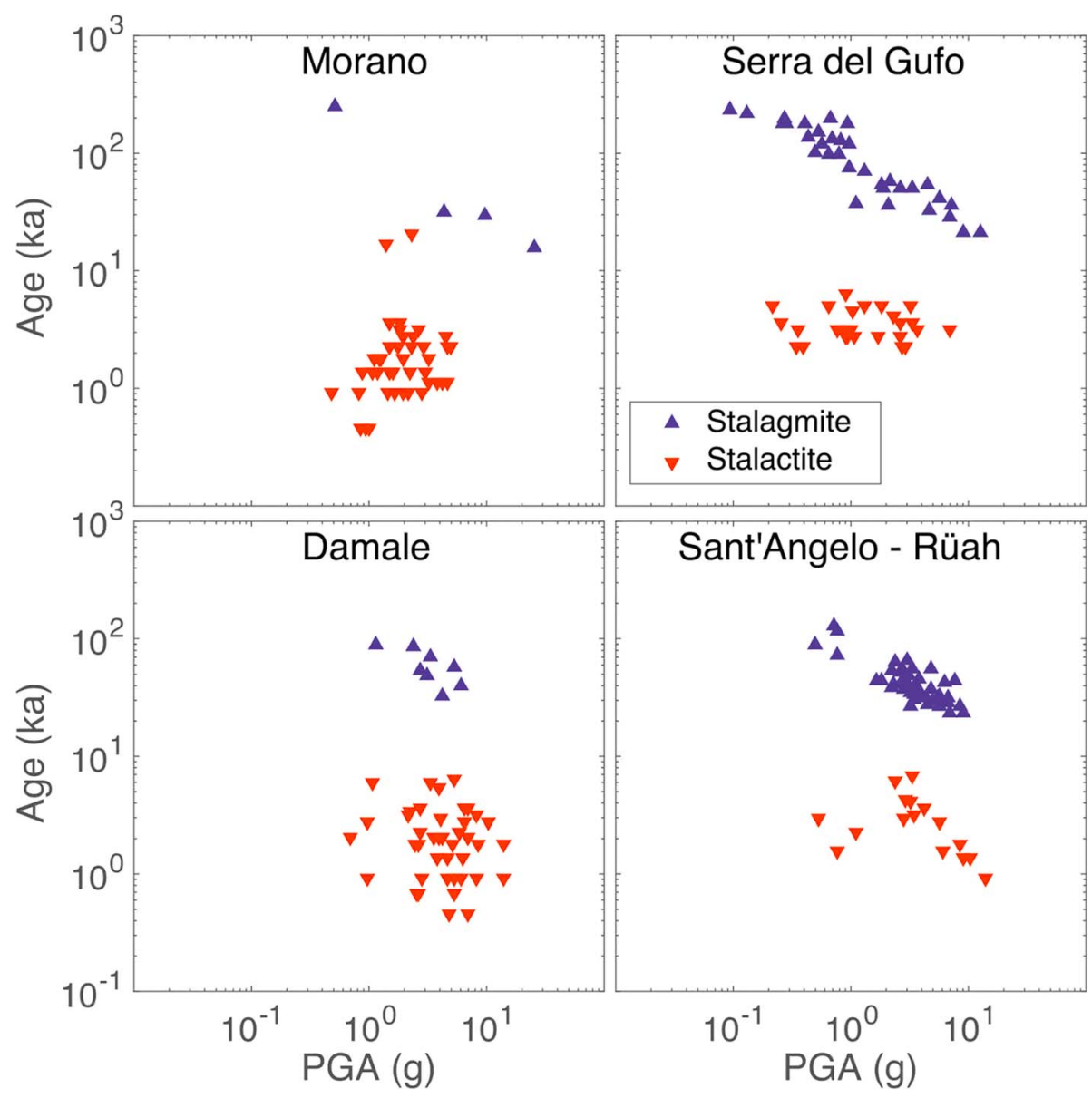

Figure 9. Inferred age versus modeled peak ground acceleration (PGA) of intact speleothems from the Pollino caves.

of seismogenic sources negligible for the seismic hazard in the area. The length of the adopted sources ranges between $\sim 10$ (CS) and $\sim 25 \mathrm{~km}$ (RS), and the long-term slip rate ranges between 0.2 and $0.9 \mathrm{~mm} /$ year.

We used kinematic, geometric, and slip rate information of each source as inputs for the FiSH code (Pace et al., 2016) to calculate the global budget of the seismic moment rate allowed by the structure (Table 4). This calculation is based on predefined size-magnitude relationships in terms of the maximum magnitude (Mmax) and associated mean recurrence time (Tmean). Results define a Mmax ranging from 6.2 (CS and EPS) to 6.7 (RS) and Tmean between $0.6 \mathrm{ka}(\mathrm{EPF})$ and $1.9 \mathrm{ka}$ (MF). As a magnitude-frequency distribution for each source, we adopted a characteristic Gaussian model, represented by a symmetric Gaussian curve centered on the Mmax value of each source with a range of magnitude equal to $1 \sigma$. Finally, we integrated

Table 4

Parameters of Seismogenic Sources Used for Seismic Input Modeling

\begin{tabular}{lccccccc}
\hline Seismogenic Source & Length $(\mathrm{km})$ & Dip angle $\left(^{\circ}\right)$ & $\begin{array}{c}\text { Seismogenic } \\
\text { thickness }(\mathrm{km})\end{array}$ & $\begin{array}{c}\text { Slip rate } \\
(\mathrm{mm} / \text { year })\end{array}$ & Mmax & Tmean (yr) & \multicolumn{1}{c}{ Reference } \\
for slip rate
\end{tabular}

Note Mmax = maximum expected magnitude; Tmean: mean recurrence time of the Mmax. 

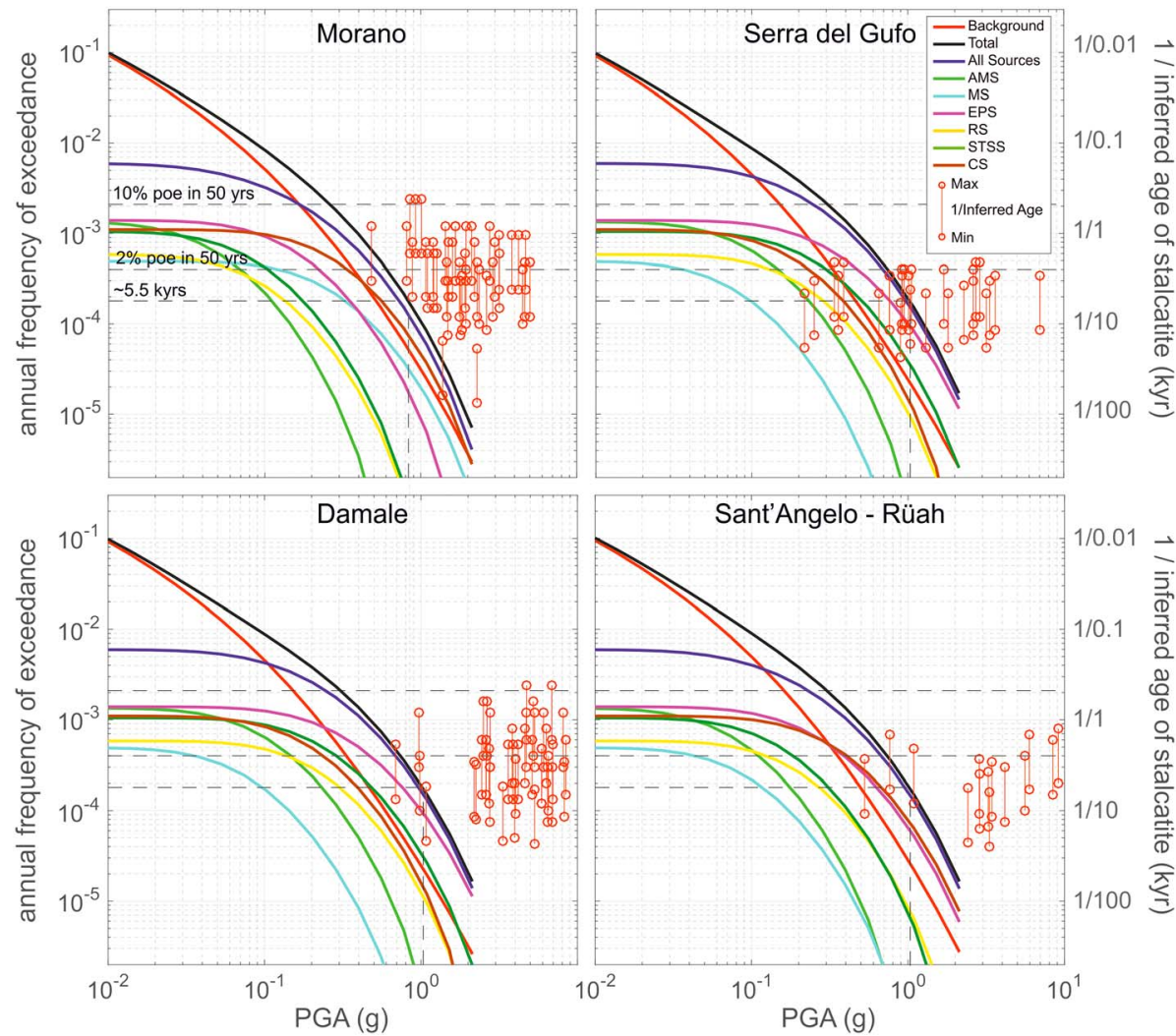

Figure 10. Seismic hazard curves (AFOE vs. PGA) for the studied caves compared to the modeled PGA of intact stalactites. AMS = Amendolara Source; MS = ; EPS = Eastern Pollino Source; RS = Rossano Source; STSS = Satanasso Source; $\mathrm{CS}=$ Castrovillari Source; PGA $=$ peak ground acceleration

in the seismic hazard estimates the distributed seismicity not associated to the seismogenic sources following the methodology proposed by Valentini et al. (2017).

The calculated hazard curves show that the contribution of the seismogenic sources to the hazard largely exceeds that of the distributed seismicity in all the caves, in particular for the two probabilities of exceedance of $0.9 \%$ and $10 \%$ in 50 years (Figure 10). Figure 10 also shows the contribution of individual seismogenic sources to the hazard at each site. The main sources that contribute to hazard at the five caves are CS for Morano, EPS for Serra del Gufo and Damale, and CS and EPS for S. Angelo Superiore and Rüah.

In addition, we carried out a deaggregation of the seismic hazard computed for the caves to define those sources that have the highest impact on the hazard. We used a "geographic deaggregation" method that separates the contribution into causative sources, magnitude, and ground motion level (Bazzurro \& Cornell, 1999; Harmsen \& Frankel, 2001). Following the methodological scheme of Pace et al. (2008), we identified the individual seismogenic source that dominates the hazard for a probability of exceedance of $10 \%$ and $2 \%$ in 50 years, for the used GMPEs that use three different distance metrics: (i) Joyner-Boore distance (Rjb); (ii) closest rupture distance (Rrup); and (iii) hypocentral distance (Rhypo). Results of deaggregation analysis (Figure 11) confirm the contribution of individual sources to hazard at each cave revealed by the hazard curves independently from the different GMPEs and from both the probability exceedances.

\section{Discussion}

\subsection{Speleoseismic Events in the Pollino Range}

Joint appraisal of the speleoseismites detected in different caves allows to single out six deformation events that affected the southern border of the Pollino Range during the last $\sim 42$ ka (Figure 6 and Table 5). These 


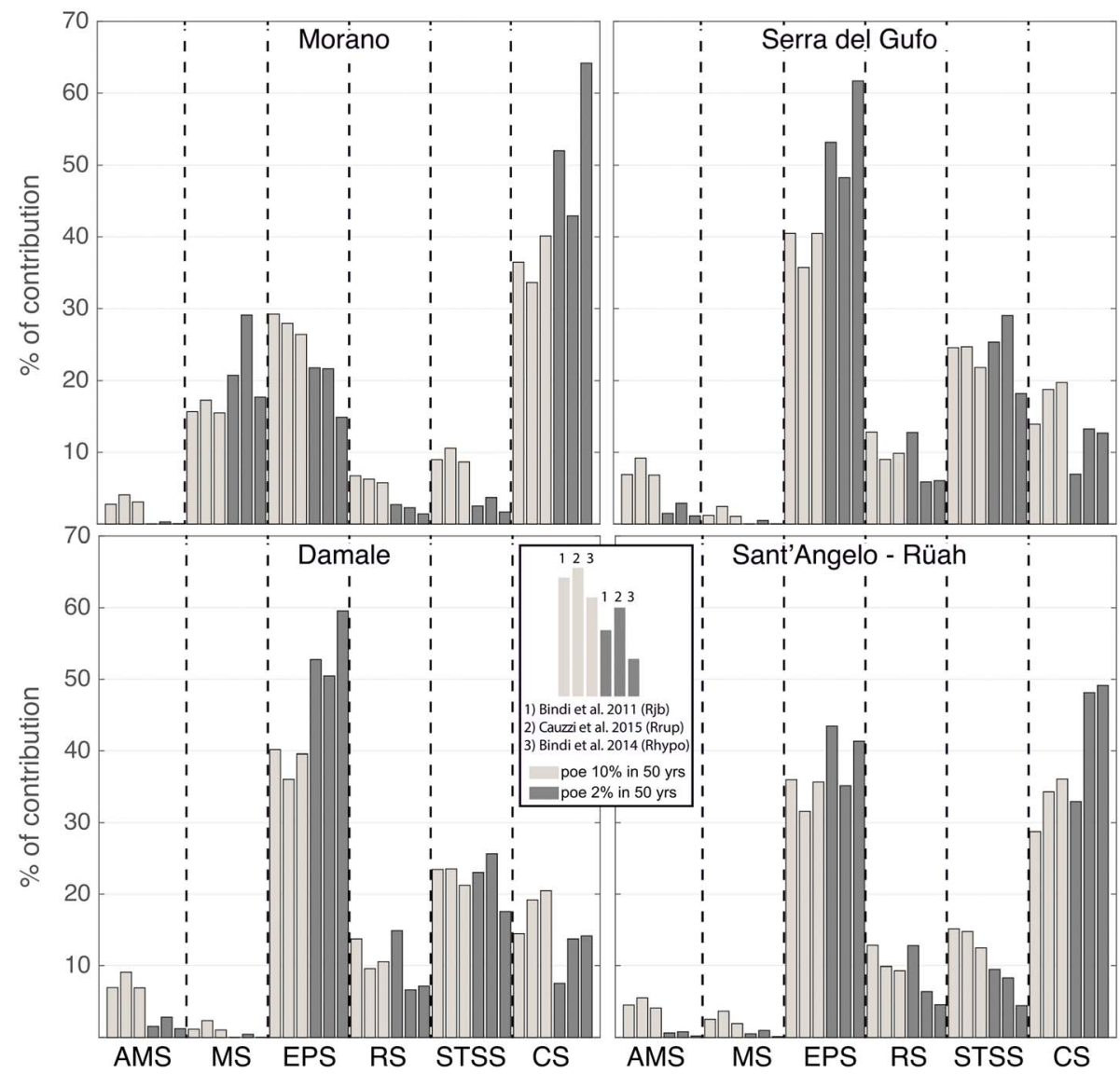

Figure 11. Deaggregation histograms of the percentage contribution to the seismic hazard at the studied Pollino caves from the modeled seismogenic sources at the 2\% and 10\% POE (Probability Of Exceedance) in 50 years. Source labels as in Figure 2. $\mathrm{AMS}=$ Amendolara Source; $\mathrm{MS}=$; EPS $=$ Eastern Pollino Source RS = Rossano Source; STSS = Satanasso Source; $\mathrm{CS}=$ Castrovillari Source; PGA = peak ground acceleration.

cumulative events are indicated with Roman numerals in Figure 6 and distinguished according to the typology (tilt or collapse of speleothems).

The oldest two events occurred between $\sim 42$ and $36 \mathrm{ka}$ and are represented by tilt of speleothem growth axes, which are recorded at S. Angelo Superiore and Damale caves. Although uncertainties for the time brackets of these events overlap, results from S. Angelo Superiore stalagmite SA7 suggest they could be assigned ages of $\sim 42-36$ and $\sim 39-36 \mathrm{ka}$, respectively (Figure 6). The intermediate tilt events recorded at Damale by stalactite D2, and possibly the oldest too, were coeval to the two SA7 tilts (Figure 6). It is likely that two of the three tilts of stalagmite S1 and fall of stalactite SA6A at S. Angelo occurred during tilt events I or II (Figure 6). The age of the events I and II falls within the widely bracketed age of the oldest two collapse events reported by Kagan et al. (2017) for the Morano Cave.

Table 5

Detected Speleoseismic Events

\begin{tabular}{lcrrcc}
\hline $\begin{array}{l}\text { Event } \\
\text { ID }\end{array}$ & $\begin{array}{c}\text { Event } \\
\text { type }\end{array}$ & \multicolumn{2}{c}{$\begin{array}{c}\text { Median } \\
\text { age (a) }\end{array}$} & $\begin{array}{c}\text { Interevent } \\
\text { time (ka) }\end{array}$ & \multicolumn{1}{c}{$\begin{array}{c}\text { Mean } \\
\text { recurrence (ka) }\end{array}$} \\
\hline VI & Collapse & 5.462 & \pm 197 & 3.310 & 5.582 \\
V & Collapse & 8.772 & \pm 756 & 8.362 & \\
IV & Collapse & 17.134 & \pm 5382 & 8.919 & \\
III & Collapse & 26.053 & \pm 729 & 11.454 & \\
II & Tilt & 37.507 & \pm 1708 & 1.448 & \\
I & Tilt & 38.955 & \pm 2833 & - & \\
\hline
\end{tabular}

Fall of soda straws at Rüah Cave between 26.7 and 25.3 ka tightly brackets a later event III (Figure 6 and Table 5). Although this event has not been recognized in the nearby S. Angelo Superiore Cave, it could have been recorded in the M. Sellaro block by fall of SG2A at Serra del Gufo and by fracturing of D1 at Damale. Within the Morano block, event III could be evidenced by fracturing of SPC4 and RFA4 at Morano Cave, although the latter events could have occurred during tilt events I or II as well. Within age uncertainty, event III overlaps with a speleoseismic event detected in the same cave by Kagan et al. (2017) through dating of a collapsed ceiling block with stalactites. 
At S. Paolo, we dated a younger ceiling block collapse (event IV) at $23-12 \mathrm{ka}$. Because of the wide age interval, this event could be recorded by fall of SG3A at Serra del Gufo and by the final tilt of SA7 at S. Angelo Superiore, but the record was not found at Rüah and Damale caves (Figure 6).

Fall event V is tightly constrained at Serra del Gufo at $\sim 9.5-8 \mathrm{ka}$. We do not have evidence for this event at nearby Damale, but it could be present at S. Angelo Superiore as tilting of SA7 (if not assigned to event IV) and fracturing of SA1 (Figure 6). We did not find direct evidence of event V at Morano Cave, although fall of RF13 and possibly of RFB1 could have occurred during this time span.

At Ramo del Fiume there are plenty of evidences (speleothems RFA1-RFA3 and likely RFB1-RFB2) of a younger fall event (VI) that occurred at 5.9-3.9 ka (Figure 6 and Table 5). Within the remaining caves, event VI could be recorded only at S. Angelo Superiore.

Summarizing, the cumulative events are sparsely documented in the visited caves (Figure 6 and Table 5). The oldest two tilt events are perhaps the most widespread and are recorded within caves of the Cassano and Sellaro blocks but not in the Morano Cave. Later collapse events (III, IV, VI, and possibly V) are documented within the Morano Cave. On the other hand, only collapse events III and V are certainly present in the speleothem record of the Cassano and Sellaro blocks.

Based on the median age of events, a mean recurrence of $\sim 5.6 \mathrm{ka}$ in the last $\sim 39 \mathrm{ka}$ is estimated, including both tilting and collapse phenomena. This estimation is slightly lower than, but comparable to the $\sim 6.5 \mathrm{ka}$ estimate for the last $\sim 45$ ka proposed by Ferranti and Maschio (2007) and the $\sim 9$ ka estimate for the last $\sim 28 \mathrm{ka}$ by Kagan et al. (2017), that the latter Authors consider a maximum for the region.

\subsection{Testing the Seismic Hazard Model}

We tested the hazard curves derived from our probabilistic seismic hazard model using unbroken speleothems because they represent fragile geological features. The latter class include objects that may be easily destroyed by strong earthquake ground motion and are mechanically simple enough to allow for analysis of the ground motion that can cause it to be destroyed (Anderson \& Brune, 1999; Brune, 1996, 1999).

Specifically, we used stalactites only because, unlike stalagmites, the modeled peak ground accelerations (PGAs) versus inferred age indicate that their fragility is age independent (Figure 9). This result ensues from the different growth mode (Figure 7). Because stalactites have an early rapid vertical growth and then develop laterally, their fragility reaches the peak value at the beginning of their concretion history and does not change much during time even with changing geometric parameters (constant aspect ratio). Instead stalagmites modify their geometry with time through vertical stacking of progressively younger layers and thus their fragility increases (Figure 7). As discussed above, the inferred age of the stalactites used to test the model, calibrated through the growth rate computation, ranges from $\sim 0.7$ to $\sim 10$ ka (Figure 9).

For Morano Cave, virtually all the stalactites data (inferred age vs. modeled PGA) fall out of the total hazard curve (Figure 10). At Serra del Gufo, $70 \%$ of the stalactites fall out of the total hazard curve, and at Damale, S. Angelo Superiore, and Rüah, the percentage increases to $~ 90 \%$. The finding that Holocene stalactites falling out of the curve are effectively not damaged is consistent with the independent estimation of the probabilistic seismic hazard model we made in the Pollino area.

Considering that the last documented speleoseismic event in the area occurred $\sim 5.5 \mathrm{ka}$ (Figure 6 and Table 5), the total hazard curves provide a PGA value equal to $\sim 0.8-1 \mathrm{~g}$ that has not been exceeded since then (Figure 10). This observation is in good agreement with the PGA estimated from speleothems modeling. Indeed, almost $90 \%$ of the modeled stalactites require a PGA value higher than $0.8 \mathrm{~g}$ able to cause the speleothem collapse and thus are not enough vulnerable to the modeled seismic input (Figure 10). These stalactites have an inferred age of between 0.7 and $10 \mathrm{ka}$ and the vast majority of them is younger than $\sim 5.5 \mathrm{ka}$ (Figure 9), and this quantitatively supports the lack of speleothem collapses in the last $\sim 5.5 \mathrm{ka}$.

\subsection{Seismotectonic and Seismic Hazard Implications}

The good fit between the seismic hazard curves and modeled unbroken speleothems highlights that the adopted seismogenic source model, including both west-dipping extensional and northeast-dipping left 
transcurrent faults, is feasible. This result is further supported by the structural observations that ENE-WSW (Da) and NNW-SSE (Db) extension axes coexist in the region (Figure 5) even in recent times, as both are recorded in cave concretions. The NNW-SSE stretching axis is compatible with left-lateral slip on NW-SE striking faults, supporting the model that these faults are active (Figure 3).

Northern Calabria is typically envisaged as dominated by active extension as it occurs elsewhere further north in the Apennines and south in the Calabrian Arc (Galli et al., 2008). The lack of strong $(\mathrm{M}>5.9)$ events in the Pollino region within historical and instrumental catalogues (Rovida et al., 2016), coupled to indications from trenching data on the $\mathrm{CF}$, prompted researchers to consider this area a prominent seismic gap (Cinti et al., 2002). Although we cannot assign the recognized speleoseismic events to specific sources, our results suggest that both normal and strike-slip faults contribute to the seismotectonic activity.

As discussed above, the frequency of recognized speleoseismic events supports the notion that in the Pollino area strong seismic events that can break speleothems have a mean recurrence time of $\sim 5.6 \mathrm{ka}$. Comparison between this observations and the seismic hazard curves indicate that the PGA threshold for collapsed speleothems every $5.6 \mathrm{ka}$ is $\sim 0.8-1.0 \mathrm{~g}$ (Figure 10). Seismological observations testify that these PGA values were achieved during strong $(\mathrm{M}>6)$ and close (epicentral distance $<12 \mathrm{~km})$ earthquakes, as for example the pulse-like records available for 24 August (Amatrice record: from Engineering Strong-Motion database-ESM, Luzi et al., 2016) and 30 October (Norcia record: Luzi et al., 2016) registrations from the 2016 Central Italy seismic sequence. In light of these observations and of our speleoseismological catalogue, we believe that the two youngest events recognized in trenches along the CF and the easternmost part of the WPF (Cinti, 2002; Cinti, Pauselli, et al., 2015; Michetti et al., 1997) have not exceeded a PGA value of $0.8 \mathrm{~g}$ at the studied caves.

Results of deaggregation analysis (Figure 11) indicate that the sources that larger contribute to the hazard at Morano Cave are CS and subordinately MS and EPS. At S. Angelo and Rüah, EPS and CS almost equally contribute to hazard. Finally, at Serra del Gufo and Damale caves the hazard is mainly driven by EPS and to a limited amount by STSS. All these selected sources can reach a PGA value larger than $0.8 \mathrm{~g}$, in light of their expected maximum magnitude (Table 4) and of the closeness to the caves (Figure 2). Therefore, we regard the mentioned sources as potential candidates for causing the observed speleoseismic events at the specific caves where they pose the greatest hazard.

\section{Conclusions}

We have integrated a classical and a novel approach in speleoseismological investigation in the Pollino region, where active tectonic rates are low, definition of seismogenic sources is difficult, and strong $(\mathrm{M}>6)$ earthquakes are infrequent and are not recorded in the historical records. The classical speleoseismological investigation relied on abundant observational data in several caves and radiometric dating of speleothem deformations, which enabled building up a robust speleoseismic inventory for the area. This includes six events in the last $\sim 42 \mathrm{ka}$, with a mean recurrence of $\sim 5.6 \mathrm{ka}$.

The classical investigation has been integrated with numerical analysis of unbroken and fragile speleothems, which provided a mean to test the goodness of an ad hoc seismogenic source and seismic hazard model for northern Calabria. This model includes both extensional seismogenic sources in the west and strike-slip seismogenic sources in the east. Results of the numerical model underline that the coexistence of both seismogenic sources is feasible, in good agreement with inversion of structural data collected both inside and outside the studied caves.

The good fit between the numerical model and the PGA threshold defined by unbroken speleothems suggests that the speleoseismological catalogue is complete for $M>6$. Considering a mean speleoseismic event recurrence of $5.6 \mathrm{ka}$ and that no large speleoseismic events have occurred in the last $5.5 \mathrm{ka}$ (Table 5), the probability of occurrence of an $M>6$ event in the area in the next few centuries is high.

Seismogenic sources MS, CS, EPS, and STSS are, among those analyzed, the best candidates for the observed speleoseismic events at different caves. Specifically, extensional sources MS and CS and strike-slip sources EPS and STSS are likely the largest contributors to the deformation observed at Morano and Sellaro blocks, 
respectively; sources CS and EPS are equally probable candidates at the intermediate Cassano block (Figure 2).

The observation that the four collapses evidenced in the last $27 \mathrm{ka}$ are all recorded at Morano Cave, whereas the Cassano and Sellaro block were affected by the older (36-42 ka) tilt events, which are not evidenced at Morano (Figure 6), further supports the activation of two types of sources with different recurrence time and foreshadows the existence of clustering phenomena.

Historical and instrumental earthquakes are only recorded west of and are spatially associated with the extensional sources. In light of the proposed tectonic activity of strike-slip sources to the east (Ferranti et al., 2009; Ferranti, Burrato, et al., 2014), and of results of our speleoseismological analysis, we infer that these sources are capable of generating earthquakes that are as strong as but less frequent than extensional earthquakes in the west.

The possibility that both extensional and strike-slip faults are active and may generate strong earthquakes is at odds with commonly accepted seismotectonics model for southern Italy. We speculate that the different behavior in terms of style of active deformation and recurrence of strong earthquakes in the Pollino range compared to the rest of Southern Apennines and Calabrian Arc derives from the peculiar geodynamic setting of the studied area. Northern Calabria spans the transition between continental subduction in the north and oceanic subduction in the south, and the deep lithospheric boundary in the lower plate may control the expression of tectonic activity in the upper plate (Figures 1a and 1b). We believe that such geodynamic setting controls the transition between extension in the west and transpression in the east and the size and recurrence of large earthquakes.

As a final remark, this study highlights that a speleoseismological approach can be fruitfully applied in other regions with low active tectonic rates and with caves where both the record of speleoseismic events and fragile intact speleothems are present. Moreover, because on-fault trenching is not always possible, the proposed approach integrates information on activity for various faults.

\section{Acknowledgments}

The research presented here greatly benefited of the enthusiastic support of Nino Larocca, chief of the Gruppo Speleologico "Sparviere" (Alessandria del Carretto, CS), who led us in the Pollino caves. We sincerely thank E. Vittori who envisaged and took part to the initial part of this research, and S. Di Bianco who helped sampling and collecting the cave data. We thank E. Kaltnecker and M. Massault for their assistance for treatments of ${ }^{14} \mathrm{C}$ samples and $\mathrm{F}$. Thil for ${ }^{14} \mathrm{C}$ analyses. We thank John Anderson (University of Nevada, Reno) and an anonymous reviewer for their constructive comments. Data supporting the conclusions of this paper can be found in the supporting information $\mathrm{S} 1$.

\section{References}

Alessio, M., Allegri, L., Bella, F., \& Improta, S. (1976). Study of the background characteristics by means of a high efficiency liquid scintillation counter. Nuclear Instruments and Methods, 137(3), 537-543. https://doi.org/10.1016/0029-554X(76)90473-0

Anderson, J. G., \& Brune, J. N. (1999). Methodology for using precarious rocks in Nevada to test seismic hazard models. Bulletin of the Seismological Society of America, 89, 456-467.

Bazzurro, P., \& Cornell, C. A. (1999). Disaggregation of seismic hazard. Bulletin of the Seismological Society of America, 89, 501-520.

Becker, A., Davenport, C. A., Eichenberger, U., Gilli, E., Jeannin, P. Y., \& Lacave, C. (2006). Speleoseismology: A critical perspective. Journal of Seismology, 10(3), 371-388. https://doi.org/10.1007/s10950-006-9017-z

Becker, A., Häuselmann, P., Eikenberg, J., \& Gilli, E. (2012). Active tectonics and earthquake destructions in caves of northern and central Switzerland. International Journal of Speleology, 41(1), 35-49. https://doi.org/10.5038/1827-806X.41.1.5

Belluomini, G., Delfino, A., Manfra, L., \& Petrone, V. (1978). Benzene synthesis for radiocarbon dating and study of the catalyst used for acetylene trimerization. International Journal of Applied Radiation and Isotopes, 29(7), 453-459. https://doi.org/10.1016/0020708X(78)90083-2

Bindi, D., Massa, M., Luzi, L., Ameri, G., Pacor, F., Puglia, R., \& Augliera, P. (2014). Pan-European ground-motion prediction equations for the average horizontal component of PGA, PGV, and $5 \%$-damped PSA at spectral periods up to $3.0 \mathrm{~s}$ using the RESORCE dataset (Vol. 12, p. 391, 2014). Bulletin of Earthquake Engineering, 12(1), 431-448. https://doi.org/10.1007/s10518-014-9589-x

Bindi, D., Pacor, F., Luzi, L., Puglia, R., Massa, M., Ameri, G., \& Paolucci, R. (2011). Ground motion prediction equations derived from the Italian strong motion database. Bulletin of Earthquake Engineering, 9(6), 1899-1920. https://doi.org/10.1007/s10518-0119313-z

Boncio, P., Mancini, T., Lavecchia, G., \& Selvaggi, G. (2007). Seismotectonics of strike-slip earthquakes within the deep crust of southern Italy: Geometry, kinematics, stress field and crustal rheology of the Potenza 1990-1991 seismic sequences (Mmax 5.7). Tectonophysics, 445(3-4), 281-300. https://doi.org/10.1016/j.tecto.2007.08.016

Bousquet, J. C., \& Gueremy, P. (1969). Quelques phenomenes de Neotectonique dans l'Apennin Calabro-Lucanien et leurs consequences morphologiques. Review of Geographical Physical and Geological Dynamics, 10, 225-238.

Bronk Ramsey, C. (2013). OxCal 4.2. Web Interface Build.

Brozzetti, F., Cirillo, D., de Nardis, R., Cardinali, M., Lavecchia, G., Orecchio, B., et al. (2017). Newly identified active faults in the Pollino seismic gap, southern Italy, and their seismotectonic significance. Journal of Structural Geology, 94, 13-31. https://doi.org/10.1016/j. jsg.2016.10.005

Brune, J. N. (1996). Precariously balanced rocks and ground-motion maps for southern California. Bulletin of Seismological Society of America, 86, 43-54.

Brune, J. N. (1999). Precarious rocks along the Mojave section of the San Andreas fault, California: Constraints on ground motion from great earthquakes. Seismological Research Letters, 70(1), 29-33. https://doi.org/10.1785/gssrl.70.1.29

Brzosko, J. S., Robouch, B. V., De Leo, R., D'erasmo, G., Pantaleo, A., Alessio, M., et al. (1986). Precise method of the local tritium breeding measurements oriented to future advanced benchmark experiments. Fusion Technology, 10(2), 253-265. https://doi.org/10.13182/ FST86-A24977 
Catalano, S., Monaco, C., Tortorici, L., \& Tansi, C. (1993). Pleistocene strike-slip tectonics in the Lucanian Apennine (Southern Italy) Tectonics, 12(3), 656-665. https://doi.org/10.1029/92TC02251

Cauzzi, C., Faccioli, E., Vanini, M., \& Bianchini, A. (2015). Updated predictive equations for broad-band (0.01-10 s) horizontal response spectra and peak ground motions, based on a global dataset of digital acceleration records. Bulletin of Earthquake Engineering. https:// doi.org/10.1007/s10518-014-9685-y

Cheng, H., Lawrence Edwards, R., Shen, C., Polyak, V. J., Asmerom, Y., Woodhead, J., et al. (2013). Improvements in 230Th dating, 230Th and 234U half-life values, and U-Th isotopic measurements by multi-collector inductively coupled plasma mass spectrometry. Earth and Planetary Science Letters, 371-372, 82-91. https://doi.org/10.1016/j.epsl.2013.04.006

Chiarabba, C., Agostinetti, N. P., \& Bianchi, I. (2016). Lithospheric fault and kinematic decoupling of the Apennines system across the Pollino range. Geophysical Research Letters, 43, 3201-3207. https://doi.org/10.1002/2015GL067610

Cinti, F. R., Alfonsi, L., D'Alessio, A., Marino, S., \& Brunori, C. B. (2015). Faulting and ancient earthquakes at Sybaris Archaeological Site, Ionian Calabria, Southern Italy. Seismological Research Letters, 89, 245-254.

Cinti, F. R., Cucci, L., Pantosti, D., D'addezio, G., \& Meghraoui, M. (1997). A major seismogenic fault in a 'silent area': The Castrovillari fault (southern Apennines, Italy). Geophysical Journal International, 130, 595-605.

Cinti, F. R., Moro, M., Pantosti, D., Cucci, L., \& D'addezio, G. (2002). New constraints on the seismic history of the Castrovillari fault in the Pollino gap (Calabria, southern Italy). Journal of Seismology, 6, 199-217.

Cinti, F. R., Pauselli, C., Livio, F., Ercoli, M., Brunori, C. A., Ferrario, F., et al. (2015). Integrating multidisciplinary, multi-scale geological and geophysical data to image the Castrovillari fault (Northern Calabria, Italy). Geophysical Journal International, 203(3), 1847-1863. https://doi.org/10.1093/gii/ggv404

Colella, A., Cremona, M., Di Bianco, S., Ferranti, L., Ramondini, M., \& Calcaterra, D. (2017). Valutazione dei principali parametri fisicomeccanici di alcuni speleotemi Italiani. In Atti III Convegno Regionale di Speleologia « Campania Speleologica », 2-4 Giugno 2017, Napoli, Italy, pp. 101-112. ISBN 978-88-89897-16-4.

Cucci, L. (2005). Geology versus myth. The Holocene evolution of the Sybaris plain. Annals of Geophysics, 48, 1017-1033.

Delaby, S. (2001). Palaeoseismic investigations in Belgian caves. Netherlands Journal of Geosciences, 80(3-4), 323-332.

DISS Working Group (2018). Database of Individual Seismogenic Sources (DISS), version 3.2.1: A compilation of potential sources for earthquakes larger than M 5.5 in Italy and surrounding areas. http://diss.rm.ingv.it/diss/, Istituto Nazionale di Geofisica e Vulcanologia. https://doi.org/10.6092/INGV.IT-DISS3.2.1

Faccenna, C., Becker, T. W., Lucente, F. P., Jolivet, L., \& Rossetti, F. (2001). History of subduction and back-arc extension in the Central Mediterranean. Geophysical Journal International, 145(3), 809-820. https://doi.org/10.1046/j.0956-540x.2001.01435.x

Faccenna, C., Molin, P., Orecchio, B., Olivetti, V., Bellier, O., Funiciello, F., et al. (2011). Topography of the Calabria subduction zone (southern Italy): Clues for the origin of Mt. Etna. Tectonics, 30, TC1003. https://doi.org/10.1029/2010TC002694

Faure Walker, J. P., Roberts, G. P., Cowie, P. A., Papanikolaou, I. D., Michetti, A. M., Sammonds, P. R., et al. (2012). Relationship between topography, rates of extension and mantle dynamics in the actively extending Italian Apennines. Earth and Planetary Science Letters, 325-326, 76-84. https://doi.org/10.1016/j.epsl.2012.01.028

Ferranti, L., Burrato, P., Pepe, F., Santoro, E., Mazzella, M. E., Morelli, D., et al. (2014). An active oblique-contractional belt at the transition between the Southern Apennines and Calabrian Arc: The Amendolara Ridge, Ionian Sea, Italy. Tectonics, 33, 2169-2194. https://doi.org/ 10.1002/2014TC003624

Ferranti, L., Improta, S., Maschio, L., \& Vittori, E. (1997). Attività tettonica recente nel massiccio del Pollino suggerita dallo studio di speleotemi fratturati. Il Quaternario, 10(2), 501-504.

Ferranti, L., \& Maschio, L. (2007). Ricerche speleosismologiche nel massiccio del Pollino, Appennino Meridionale, Atti I Convegno Regionale di Speleologia “Campania Speleologica”, 1-3 giugno 2007, Oliveto Citra (SA), pp. 201-215.

Ferranti, L., Milano, G., \& Pierro, M. (2017). Insights on the seismotectonics of the western part of northern Calabria (southern Italy) by integrated geological and geophysical data: Coexistence of shallow extensional and deep strike-slip kinematics. Tectonophysics, 721, 372-386. https://doi.org/10.1016/j.tecto.2017.09.020

Ferranti, L., Pagliarulo, R., Antonioli, F., \& Randisi, A. (2011). Punishment of the sinner: Holocene episodic subsidence and steady tectonic motion at ancient Sybaris (Calabria, southern Italy). Quaternary International, 232(1-2), 56-70. https://doi.org/10.1016/j. quaint.2010.07.014

Ferranti, L., Palano, M., Cannavo, F., Mazzella, M. E., Oldow, J. S., Gueguen, E., et al. (2014). Rates of geodetic deformation across active faults in southern Italy. Tectonophysics, 621, 101-122. https://doi.org/10.1016/j.tecto.2014.02.007

Ferranti, L., Santoro, E., Mazzella, M. E., Monaco, C., \& Morelli, D. (2009). Active transpression in the northern Calabria Apennines, Southern Italy. Tectonophysics, 476, 226-251. https://doi.org/10.1016/j.tecto.2008.11.010

Forti, P. (2001). Seismotectonic and paleoseismic studies from speleothems: The state of the art. Netherlands Journal of Geosciences, 80(3-4), $175-185$.

Forti, P., \& Postpischl, D. (1984). Seismotectonic and paleoseismic analyses using karst sediments. Marine Geology, 55(1-2), 145-161. https://doi.org/10.1016/0025-3227(84)90138-5

Galadini, F., Meletti, C., \& Rebez, A. (Eds) (2000). Le ricerche del GNDT nel campo della pericolosità sismica (1996-1999). Roma (p. 397). Italy: CNR-Gruppo Nazionale per la Difesa dai Terremoti.

Galdenzi, S. (1997). Initial geologic observations in caves bordering the Sibari Plain (Southern Italy). Journal Cave Karst Studies, 59(2), 81-86.

Galli, P., Galadini, F., \& Pantosti, D. (2008). Twenty years of paleoseismology in Italy. Earth-Science Reviews, 88, 89-117. https://doi.org/ 10.1016/j.earscirev.2008.01.001

Galli, P., Spina, V., Ilardo, I., \& Naso, G. (2010). Evidence of active tectonics in Southern Italy: The Rossano fault (Calabria). In P. Guarnieri (Ed.), Recent progress on earthquake geology, (pp. 49-78). NF, United States: Nova Science Publishers.

Genty, D., \& Massault, M. (1997). Bomb 14C recorded in laminated speleothems: Calculation of dead carbon proportion. Radiocarbon, 39(01), 33-48. https://doi.org/10.1017/S0033822200040881

Ghisetti, F., \& Vezzani, L. (1982). Strutture tensionali e compressive indotte da meccanismi profondi lungo la linea del Pollino (Appennino meridionale). Bollettino della Societa Geologica Italiana, 101, 385-440.

Gilli, E., \& Delange, P. (2001). Utilisation des spéléothèmes comme indicateurs de néotectonique ou de la paléosismicité. In E. Gilli \& P. Audra (Eds.), Tectonique active et géomorphologie, Revue d'Analyse Spatiale Quantitative et Appliquée, Special Publication (pp. 79-90).

Gribovszki, K., Esterhazy, S., \& Bokelmann, G. (2018). Numerical modeling of stalagmite vibrations. Pure and Applied Geophysics, 175(12), 4501-4514. https://doi.org/10.1007/s00024-018-1952-4 
Harmsen, S., \& Frankel, A. (2001). Geographic deaggregation of seismic hazard in the United States. Bulletin of the Seismological Society of America, 91(1), 13-26. https://doi.org/10.1785/0120000007

Hyppolite, J. C., Angelier, J., \& Roure, F. (1994). A major geodynamic change revealed by Quaternary stress patterns in the Southern Apennines (Italy). Tectonophysics, 230, 199-210. https://doi.org/10.1016/0040-1951(94)90135-X

Improta, S., Ferranti, L., Vittori, E., \& Alessio, M. (1997). Investigation of recent tectonic activity in the Pollino massif, South Italy, by means of $14 \mathrm{C}$ dating of deformed speleothems. Paper presented at $16^{\text {th }}$ International Radiocarbon Conference, Groningen, Germany.

Jaffey, A. H., Flynn, K. F., Glendenin, L. E., Bentley, W. C., \& Essling, A. M. (1971). Precision measurements of half-lives and specific activities of ${ }^{235} \mathrm{U}$ and ${ }^{238} \mathrm{U}$. Physical Review, C4, 1889-1906.

Jaillet, S., Pons-Branchu, E., Maire, R., Hamelin, B., \& Brulhet, J. (2006). Enregistrement de paléo-mises en charge Holocènes dans deux stalagmites du réseau du rupt-du-puits (Barrois, France). Analyses morphologiques des lamines et datations U/Th en TIMs. Geologica Belgica, 9(3-4), 297-307.

Kagan, E.J. (2012). Multi-site Late Quaternary paleoseismology in the Dead Sea Transform Region: independent recording by lake and cave sediments, Geological Survey of Israel report, GSI/17/2012.

Kagan, E. J., Agnon, A., Bar-matthews, M., \& Ayalon, A. (2005). Dating large infrequent earthquakes by damaged cave deposits. Geology, 33(4), 261-264. https://doi.org/10.1130/G21193.1

Kagan, E. J., Cinti, F. R., Alfonsi, L., Civico, R., \& Bar-matthews, M. (2017). Broken speleothems reveal Holocene and Late Pleistocene paleoearthquakes in Northern Calabria, Italy. Quaternary International, 451, 176-184. https://doi.org/10.1016/j. quaint.2016.10.023

Lacave, C., Koller, M. G., \& Egozcue, J. J. (2004). What can be concluded about seismic history from broken and unbroken speleothems? Journal of Earthquake Engineering, 8(3), 431-455. https://doi.org/10.1080/13632460409350496

Lanzano, G., Luzi, L., Rotondi, R., Varini, E., \& Marzocchi, W. (2017). Selection and ranking of the ground motion prediction equations for the new Italian hazard map (MPS16). Paper presented at $36^{\text {th }}$ Conference of Gruppo Nazionale Geofisica della Terra Solida (GNGTS), 36, 282-285, ISBN: 978-88-940442-8-7.

Larocca, F. (1991). Le Grotte della Calabria. Guida alle maggiori cavità carsiche della regione. Martinafranca (Taranto, Italy): Nuova Editrice Apulia.

Lemeille, F., Cushing, M., Carbon, D., Grellet, B., Bitterli, T., Flehoc, C., \& Innocent, C. (1999). Co-seismic ruptures and deformations recorded by speleothems in the epicentral zone of the Basel earthquake. Geodinamica Acta, 12(3-4), 179-191.

Ludwig, K. R., \& Titterington, D. M. (1994). Calculation of ${ }^{230} \mathrm{Th} / \mathrm{U}$ isochrons, ages, and errors. Geochimica et Cosmochimica Acta, 58(22), 5031-5042. https://doi.org/10.1016/0016-7037(94)90229-1

Luzi, L., Puglia, R., Russo, E., \& ORFEUS WG5 (2016). Engineering strong motion database, version 1.0. Istituto Nazionale di Geofisica e Vulcanologia, Observatories \& Research Facilities for European Seismology. https://doi.org/10.13127/ESM

Maschio, L., Ferranti, L., \& Burrato, P. (2005). Active extension in Val dAgri area, Southern Apennines, Italy: Implications for the geometry of the seismogenic belt. Geophysical Journal International, 162(2), 591-609, ISSN: 0956-540X. https://doi.org/10.1111/j.1365246X.2005.02597.X

Michetti, A. M., Ferreli, L., Serva, L., \& Vittori, E. (1997). Geological evidence for strong historical earthquakes in an "aseismic" region: The Pollino case (Southern Italy). Journal of Geodynamics, 24(1-4), 61-86.

Noronha, A. L., Johnson, K. R., Hu, C., Ruan, J., Southon, J. R., \& Ferguson, J. E. (2014). Assessing influences on speleothem dead carbon variability over the Holocene: Implications for speleothem-based radiocarbon calibration. Earth and Planetary Science Letters, 394, $20 \mathrm{e} 29$.

Pace, B., Boncio, P., Brozzetti, F., Lavecchia, G., \& Visini, F. (2008). From regional seismic hazard to "scenario earthquakes" for seismic microzoning: A new methodological tool for the Celano Project. Soil Dynamics and Earthquake Engineering, 28(10-11), 866-874. https://doi.org/10.1016/j.soildyn.2007.11.001

Pace, B., Peruzza, L., Lavecchia, G., \& Boncio, P. (2006). Layered seismogenic source model and probabilistic seismic-hazard analyses in central Italy. Bulletin of the Seismological Society of America, 96(1), 107-132. https://doi.org/10.1785/0120040231

Pace, B., Visini, F., \& Peruzza, L. (2016). FiSH: MATLAB tools to turn fault data into seismic-hazard models. Seismological Research Letters, 87(2A), 374-386. https://doi.org/10.1785/0220150189

Pagani, M., Monelli, D., Weatherill, G., Danciu, L., Crowley, H., Silva, V., et al. (2014). OpenQuake-engine: An open hazard (and risk) software for the Global Earthquake Model. Seismological Research Letters, 85(3), 1-13.

Papanikolau, I. D., \& Roberts, G. P. (2007). Geometry, kinematics and deformation rates along the active normal fault system in the southern Apennines: Implications for fault growth. Journal of Structural Geology, 29(1), 166-188. https://doi.org/10.1016/j. jsg.2006.07.009

Patacca, E., Sartori, R., \& Scandone, P. (1990). Tyrrhenian basin and Apenninic arcs. Kinematic relations since late Tortonian times. Memorie della Societa Geologica Italiana, 45, 425-451.

Perez-Lopez, R., Rodriguez-Pascua, M. A., Giner-Robles, J. L., Martinez-Diaz, J. J., Marcos-Nuez, A., Silva, P. G., et al. (2009). Speleoseismology and palaeoseismicity of Benis Cave (Murcia, SE Spain): Coseismic effects of the 1999 Mula earthquake (mb 4.8). In K. Reicherter, A. M. Michetti, \& P. G. Silva (Eds.), Palaeoseismology: Historical and prehistorical records of earthquake ground effects for seismic hazard assessment, Geological Society London Special Publications (Vol. 316, pp. 207-216).

Peruzza, L., Pace, B., \& Cavallini, F. (2010). Error propagation in time-dependent probability of occurrence for characteristic earthquakes in Italy. Journal of Seismology, 14(1), 119-141. https://doi.org/10.1007/s10950-008-9131-1

Pons-Branchu, E., Douville, E., Roy-Barman, M., Dumont, E., Branchu, P., Thil, F., et al. (2014). A geochemical perspective on Parisian urban history based on U-Th dating, laminae counting and yttrium and REE concentrations of recent carbonates in underground aqueducts. Quaternary Geochronology, 24, 44-53. https://doi.org/10.1016/j.quageo.2014.08.001

Pons-Branchu, E., Hamelin, B., Brulhet, J., \& Bruxelles, L. (2004). Speleothem rupture in karst: tectonic or climatic origin? U-Th dating of rupture events in Salamandre Cave (Gard, South-Eastern France). Bulletin de la Société Géologique de France, 175(5), 473-479. https:// doi.org/10.2113/175.5.473

Postpischl, D., Agostini, S., Forti, P., \& Quinif, Y. (1991). Paleoseismicity from karst sediments: The “Grotta dei Cervi” cave case study. Tectonophysics, 193, 33-44.

Presti, D., Billi, A., Orecchio, B., Totaro, C., Faccenna, C., \& Neri, G. (2013). Earthquake focal mechanisms, seismogenic stress, and seismotectonics of the Calabrian Arc, Italy. Tectonophysics, 602, 153-175. https://doi.org/10.1016/j.tecto.2013.01.030

Reimer, P. J., Bard, E., Bayliss, A., Beck, J. W., Blackwell, P. G., Ramsey, C. B., et al. (2013). IntCal13 and Marine13 radiocarbon age calibration curves 0-50,000 years cal BP. Radiocarbon, 55(4), 1869-1887. https://doi.org/10.2458/azu_js_rc.55.16947

Reimer, P. J., Brown, T. A., \& Reimer, R. W. (2004). Discussion: Reporting of ${ }^{14}$ C data. Radiocarbon, 19(3), 355-363. 
Rovida, A., Locati, M., Camassi, R., Lolli, B., \& Gasperini, P. (2016). CPTI15, the 2015 version of the parametric catalogue of Italian earthquakes. Istituto Nazionale di Geofisica e Vulcanologia. https://doi.org/10.6092/INGV.IT-CPTI15

Russo, F., \& Schiattarella, M. (1992). Osservazioni preliminari sull'evoluzione morfostrutturale del bacino di Castrovillari. Studi Geologici Camerti, 1, 271-278.

Sanchidrián, J. L., Valladas, H., Medina-Alcaide, M. A., Pons-Branchu, E., \& Quiles, A. (2017). New perspectives for 14C dating of parietal markings using $\mathrm{CaCO}_{3}$ thin layers: An example in Nerja cave (Spain). Journal of Archaeological Science: Reports, 12, 74-80. https://doi. org/10.1016/j.jasrep.2017.01.028

Santoro, E., Ferranti, L., Burrato, P., Mazzella, M. E., \& Monaco, C. (2013). Deformed Pleistocene marine terraces along the Ionian Sea margin of southern Italy: Unveiling blind fault-related folds contribution to coastal uplift. Tectonics, 32, 737-762. https://doi.org/ $10.1002 /$ tect. 20036

Santoro, E., Mazzella, M. E., Ferranti, L., Randisi, A., Napolitano, E., Rittner, S., \& Radtke, U. (2009). Raised coastal terraces along the Ionian Sea coast of northern Calabria, Italy, suggest space and time variability of tectonic uplift rates. Quaternary International, 206(1-2), 78-101, ISSN: 1040-6182. https://doi.org/10.1016/j.quaint.2008.10.003

Schiattarella, M. (1998). Quaternary tectonics of the Pollino Ridge, Calabria-Lucania boundary, southern Italy. In R. Holdsworth, R. E. Strachan, \& R. A. Dewey (Eds.), Continental transpressional and transtensional tectonics, Geological Society London Special Publications (Vol. 135, pp. 341-345).

Spina, V., Tondi, E., Galli, P., \& Mazzoli, S. (2009). Fault propagation in a seismic gap area (northern Calabria, Italy): Implications for seismic hazard. Tectonophysics, 476(1-2), 357-369. https://doi.org/10.1016/j.tecto.2009.02.001

Stuiver, M., \& Polach, H. A. (1977). Discussion reporting of ${ }^{14} \mathrm{C}$ data. Radiocarbon, 19(03), 355-363. https://doi.org/10.1017/ S0033822200003672

Tansi, C., Muto, F., Critelli, S., \& Iovine, G. (2007). Neogene-Quaternary strike-slip tectonics in the central Calabrian Arc (southern Italy). Journal of Geodynamics, 43, 393-414. https://doi.org/10.1016/j.jog.2006.10.006

Tertulliani, A., \& Cucci, L. (2014). New insights on the strongest historical earthquake in the Pollino region (southern Italy). Seismological Research Letters, 85, 743-751. https://doi.org/10.1785/0220130217

Tisnérat-Laborde, N., Poupeau, J. J., Tannau, J. F., \& Paterne, M. (2001). Development of a semi-automated system for routine preparation of carbonate sample. Radiocarbon, 43(2A), 299-304. https://doi.org/10.1017/S0033822200038145

Totaro, C., Presti, D., Billi, A., Gervasi, A., Orecchio, B., Guerra, I., \& Neri, G. (2013). The ongoing seismic sequence at the Pollino mountains, Italy. Seismological Research Letters, 84(6), 955-962. https://doi.org/10.1785/0220120194

Valentini, A., Visini, F., \& Pace, B. (2017). Integrating faults and past earthquakes into a probabilistic seismic hazard model for peninsular Italy. Natural Hazards and Earth System Sciences, 17(11), 2017-2039. https://doi.org/10.5194/nhess-17-2017-2017

Van Dijk, J. P., Bello, M., Brancaleoni, G. P., Cantarella, G., Costa, V., Frixa, A., et al. (2000). A regional structural model for the northern sector of the Calabrian Arc (southern Italy). Tectonophysics, 324(4), 267-320. https://doi.org/10.1016/S0040-1951(00)00139-6

Wells, D. L., \& Coppersmith, K. L. (1994). New empirical relationships among magnitude, rupture length, rupture width, rupture area, and surface displacement. Bulletin of the Seismological Society of America, 84(4), 974-1002. 